\title{
The onset of Walvis Ridge: Plume influence at the continental margin
}

\author{
T. Fromm ${ }^{\text {a,* }}$, W. Jokat ${ }^{\text {a }}$, T. Ryberg ${ }^{\text {c }}$, J.H. Behrmann ${ }^{\text {b }}$, C. Haberland ${ }^{\text {c }}$, M. Weber ${ }^{\text {c,d }}$ \\ a Alfred-Wegener-Institut für Polar-und Meeresforschung, Am Alten Hafen 26, D-27568, Bremerhaven, Germany \\ b GEOMAR, Helmholtz Centre for Ocean Research Kiel, Wischhofstr. 1-3, D-24148 Kiel, Germany \\ c Helmholtz-Centre Potsdam, - German Research Centre for Geosciences (GFZ), Telegrafenberg, D-14473 Potsdam, Germany \\ ${ }^{d}$ University of Potsdam, Institute of Earth and Environmental Science, Golm, D-14471 Potsdam, Germany
}

\section{A R T I C L E I N F O}

\section{Article history:}

Received 1 February 2016

Received in revised form 17 March 2017

Accepted 20 March 2017

Available online 27 March 2017

\begin{abstract}
A B S T R A C T
The opening of the South Atlantic is a classical example for a plume related continental breakup. Flood basalts are present on both conjugate margins as well as aseismic ridges connecting them with the current plume location at Tristan da Cunha. To determine the effect of the proposed plume head on the continental crust, we acquired wide-angle seismic data at the junction of the Walvis Ridge with the African continent and modelled the Pwave velocity structure in a forward approach. The profile extends $430 \mathrm{~km}$ along the ridge and continues onshore to a length of $720 \mathrm{~km}$. Crustal velocities beneath the Walvis Ridge vary between $5.5 \mathrm{~km} / \mathrm{s}$ and $7.0 \mathrm{~km} / \mathrm{s}$, a typical range for oceanic crust. The crustal thickness of $22 \mathrm{~km}$, however, is approximately three times larger than of normal oceanic crust. The continent-ocean transition is characterized by $30 \mathrm{~km}$ thick crust with strong lateral velocity variations in the upper crust and a high-velocity lower crust (HVLC), where velocities reach up to $7.5 \mathrm{~km} / \mathrm{s}$. The HVLC is 100 to $130 \mathrm{~km}$ wider at the Walvis Ridge than it is farther south, and impinges onto the continental crust of the Kaoko fold belt. Such high seismic velocities indicate Mg-rich igneous material intruded into the continental crust during the initial rifting stage. However, the remaining continental crust seems unaffected by intrusions and the root of the $40 \mathrm{~km}$-thick crust of the Kaoko belt is not thermally abraded. We conclude that the plume head did not modify the continental crust on a large scale, but caused rather local effects. Thus, it seems unlikely that a plume drove or initiated the breakup process. We further propose that the plume already existed underneath the continent prior to the breakup, and ponded melt erupted at emerging rift structures providing the magma for continental flood basalts.
\end{abstract}

(c) 2017 Elsevier B.V. All rights reserved.

\section{Introduction}

A problem in modern plate tectonics is to understand the driving forces controlling plate movements. Several mechanisms are discussed: plate boundary forces such as ridge push and slab pull, mantle convection-induced basal drag, gravitational potential and buoyancy forces from deep mantle plumes. Although all potentially influence plate movements their relationship and relative significance are still unclear. It is not understood, how and why continents break and which parameters and features determine the line of breakup. Large forces are required to break continents by pure extension, although several processes can reduce the required forces and facilitate breakup, e.g. the stress distribution and geometry of rifting (Brune et al., 2012). Regarding the line of breakup, an increasing amount of evidence indicates that large plates preferentially separate along lines of weakness, which are reactivated by underlying mantle processes (Ziegler and Cloetingh, 2004; Lundin and Doré, 2005; Buiter and Torsvik, 2014). Lines of weakness can be old fracture zones, former plate boundaries or areas of

\footnotetext{
* Corresponding author.

E-mail address: Tanja.Fromm@awi.de (T. Fromm).
}

repeated extension and compression (Lundin and Doré, 2011). In addition to utilizing old weak zones, some processes generate new ones. Hot lithosphere is weaker than cold lithosphere, thus processes increasing the lithosphere's temperature can be important. For example, large mantle convection cells may accumulate hot upwelling material beneath continental plates, increasing the temperature and therefore weakening the crust until it finally gives way (Gurnis, 1988). Another common explanation for increased temperatures is deep mantle plumes transporting hot material from the core mantle boundary to the upper mantle. When plume heads reach the base of the lithosphere, it is thermally eroded, allowing large amounts of decompression melts to intrude the crust and erupt at the surface, forming Large Igneous Provinces (LIPs: Morgan, 1971; Courtillot et al., 1999; Sobolev et al., 2011). After the main phase of eruptions the plume head is no longer relevant for on-going volcanism, however, the model predicts that the thin remaining tail can produce linear age-progressive volcanic ridges or seamounts as the plate moves over the plume position. For midocean ridge-centred plumes, pairs of aseismic ridges are created on the diverging plates. Because LIPs are commonly found in combination with rift systems and their main eruptions occur prior to or close to the rift-drift transition (Courtillot et al., 1999), plumes have been 
considered as the major cause for continental breakup (Morgan, 1971; Richards et al., 1989), or are at least thought to enhance rifting and significantly increase the chances for breakup (Ziegler and Cloetingh, 2004; Brune et al., 2013). Although the plume model is widely used, it is at the same time controversial. Several studies question the influence of mantle plumes on continental breakup, e.g. Anderson (2001); McHone (2000); Fromm et al. (2015). Examples for LIPs in close connection with breakup and hotspot trails are found in the Indian Ocean and in the North Atlantic. The Deccan traps in India connect to the Reunion hotspot via the Mascarene-Chagos-Laccadive Ridge (Collier et al., 2009), the Ninetyeast Ridge in the Indian Ocean marks the Kerguelen hotspot trail (Grevemeyer and Flueh, 2000) and in the North Atlantic the Iceland-Faroe Ridge (Richardson et al., 1998) and the IcelandGreenland Ridge (Holbrook et al., 2001) connect Iceland to the North Atlantic Volcanic Province. However, some ridges cannot easily be associated with a LIP or rifting processes, but are still candidates for plumelithosphere interactions. Examples are Emperor-Hawaiian hotspot trail or the Cocos and Carnegie ridges, forming the surface expression of the Galapagos hotspot. The Emperor-Hawaiian track lacks a LIP at its beginning and the Galapagos hotspot is in spatial correlation with the Caribbean large igneous province, but disagreements with the timing and tectonic models question the relation to the Galapagos hotspot (Meschede and Frisch, 1998).

The opening of the South Atlantic is another classical example for plume related continental breakup. Continental flood basalts are present on both conjugate margins and a pair of aseismic ridges marks the plume trail to the current hotspot position (Fig. 1). The Paraná flood basalt province in South America was emplaced prior and during the rift phase some 137 to $127 \mathrm{Ma}$ ago (Turner et al., 1994). The conjugate Etendeka flood basalts in Namibia have ages of peak volcanism at 132-129 Ma (Renne et al., 1996). Because of its proximity to the study area, the Etendeka province and the basement geology around it are worth describing in more detail.

Based on differences in the lava geochemistry and volcanic stratigraphy, the Etendeka province is divided into a northern and southern part (Fig. 2) of equivalent age. The southern Etendeka province is the larger of the two, and located at the northern edge of the Damara Fold Belt. The Damara Fold Belt formed between 535 and 505 Ma during the amalgamation of Gondwana when the Congo and Kalahari cratons collided (Foster et al., 2009). The northern Etendeka province covers a smaller area along the coast near the landfall of the Walvis Ridge, which is subject of this paper. It is hosted within the Kaoko Fold belt, a coast-parallel mountain belt formed between 590 and $550 \mathrm{Ma}$ (Foster et al., 2009).

After the emplacement of the continental flood basalts, the Walvis Ridge formed on the African plate while it moved over the stationary plume tail. The persistent volcanism formed the remarkable submarine ridge stretching $3100 \mathrm{~km}$ from the African continent almost to the present-day Mid-Atlantic Ridge (Fig. 1). Basalt ages progressively decrease away from the continent. From $114 \mathrm{Ma}$ at the northeastern end close to the Namibian coast, to 27-49 Ma in the southwestern Guyot province. The most recent eruptions at the proposed present-day hotspot position, Tristan da Cunha island (O'Connor and Duncan, 1990; Rohde et al., 2012), happened in 1961. Since the dated samples are not evenly distributed along the entire Walvis Ridge, the age progression of the older part of the ridge up to magnetic anomaly C34 (83.5 Ma, Gee and Kent, 2007) is poorly constrained. Only two closely spaced dredges provide age constrains and ODP (Ocean drilling Program) wells in this area did not reach the basement (Leg 40, Sites 362, 363 and Leg 75, Site 530532; Bolli et al., 1978; Hay and Sibuet, 1984). Magnetic anomalies M0 and M4 are found south of the Walvis Ridge close to the Namibian margin, but not on the ridge itself or north of it (Cande et al., 1989; Nürnberg and Müller, 1991; Eagles, 2007).

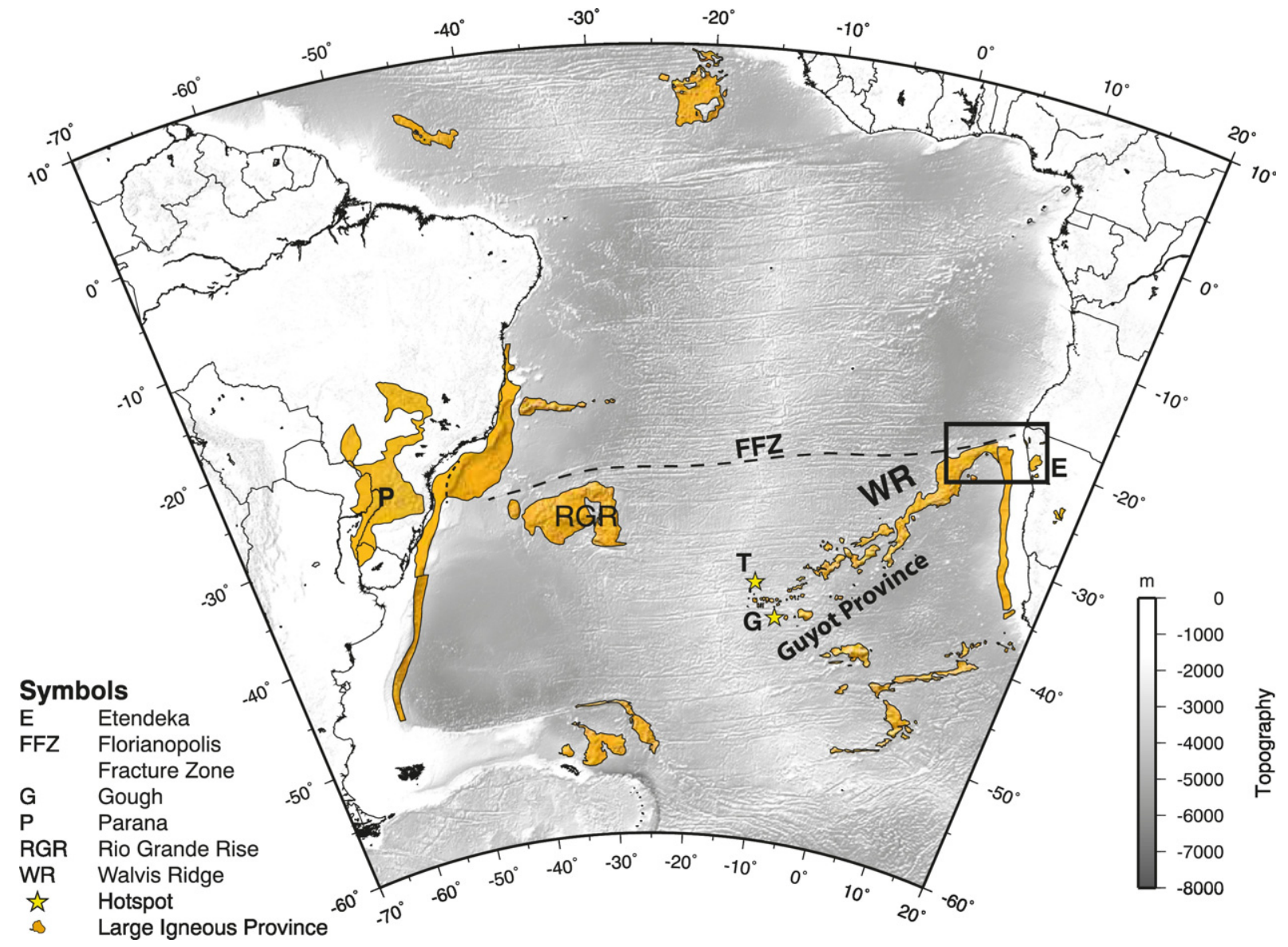

Fig. 1. Overview map of the South Atlantic. The research area is marked by a black box. 


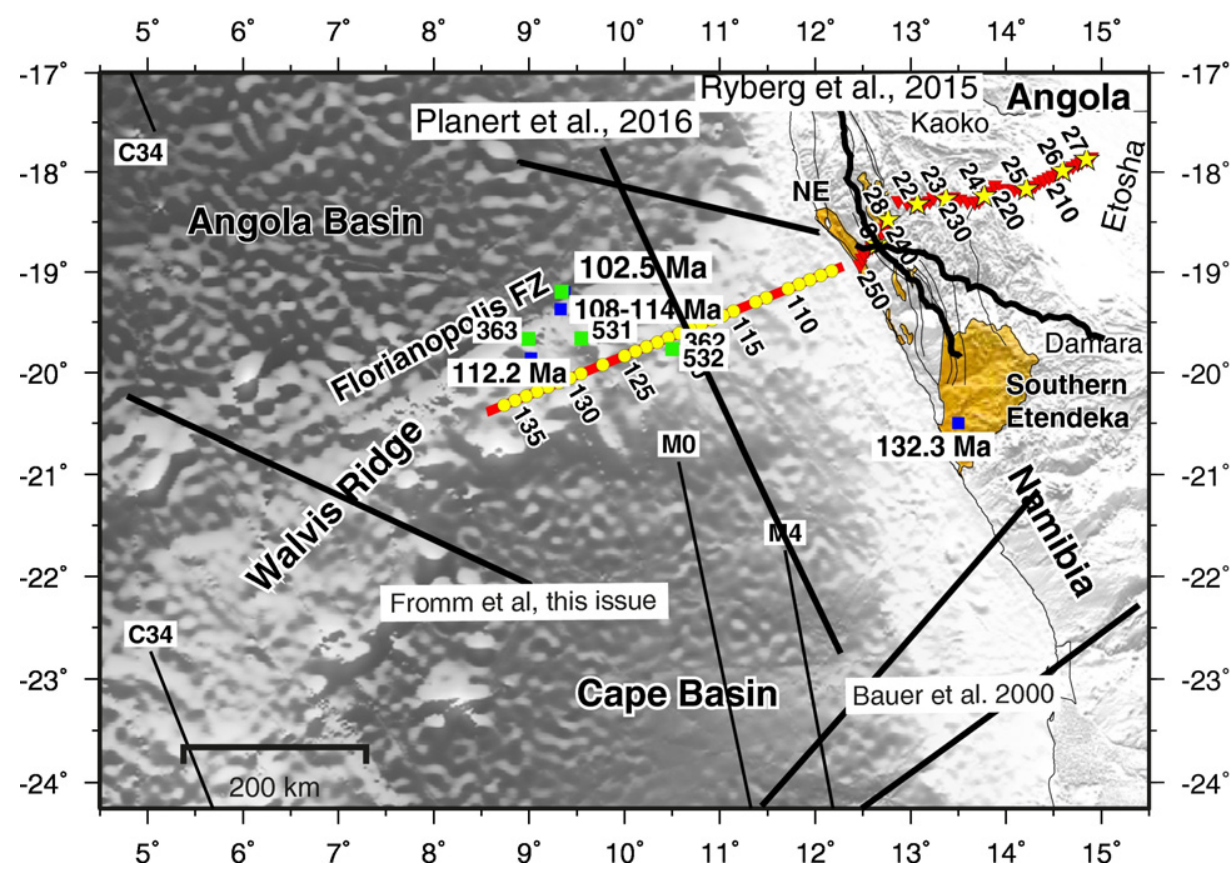

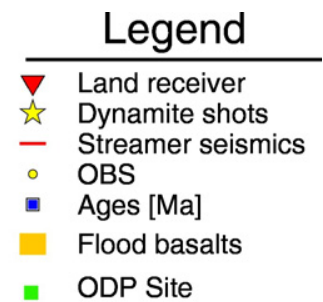

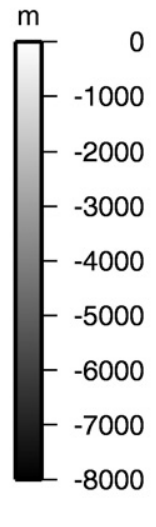

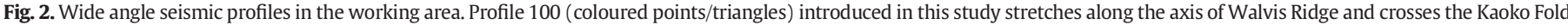

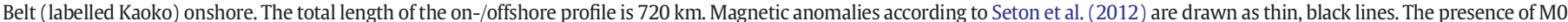

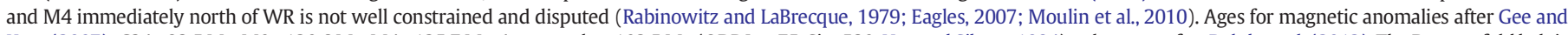

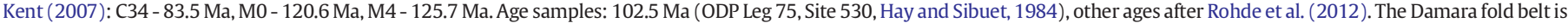
labelled with Damara only.

The conjugate Rio Grande Rise on the South American plate lacks the continuity and elongate shape of the Walvis Ridge and was likely formed when the hotspot was located beneath the Mid-Atlantic Ridge, a situation similar to present day Iceland (O'Connor and Duncan, 1990). After $80 \mathrm{Ma}$ the volcanism changed from on-axis to intra-plate, resulting in the formation of the guyot province without corresponding features on the South American plate (O'Connor and Duncan, 1990). During the hotspot evolution, magma production was generally diminished and not constant. It varied with periods of 10-20 and $5 \mathrm{Ma}$ (Adam et al., 2007; Gallagher and Hawkesworth, 1994).

Even though the general model for the evolution of the Walvis Ridge is widely accepted, the existence/role of a mantle plume is still controversial and different processes for the formation of the ridge are discussed. The Walvis Ridge might be also a result of the evolution of a fracture zone with an extensional component (a failed rift arm of a triple junction) producing the volcanism (Le Pichon and Fox, 1971; Fairhead and Wilson, 2005; Elliott et al., 2009) or a combination of hotspot and fracture zone (Haxel and Dziak, 2005). Those models are based on the proximity of the Walvis Ridge to the Florianopolis Fracture Zone (FFZ, Fig. 1), a major fracture in the South Atlantic marking the northern boundary of the Walvis Ridge. The FFZ can be traced across the Mid-Atlantic Ridge and has been an active deformation zone in South America (Torsvik et al., 2009, and references therein).

Thus, the Walvis Ridge is an excellent location to study breakup mechanism with hotspot influence and test the previously described models. Fromm et al. (2015) and Planert et al. (2017) showed that the Walvis Ridge consists of high seismic velocities in the lower crust, but this high velocity zone is limited to the continent ocean transition and a very small area beneath the continent. Here, we present more detailed results of the combined on-/offshore wide-angle seismic profile published in Fromm et al. (2015) along the crest of the Walvis Ridge and the adjacent Namibian continental margin (Fig. 2) and complement the analysis with gravity modelling. The profile extends $430 \mathrm{~km}$ along the axis of Walvis Ridge, and a further $290 \mathrm{~km}$ onshore into the Kaoko Belt of Namibia. The aim was to investigate the crustal fabric at the transition zone between flood volcanism and the onset of the ridge formation. We were especially interested to determine how far the continental crust was modified landwards by this magmatism and if there are traces of a large plume head.

\section{Data acquisition, processing and modelling}

Here we present one of five wide-angle seismic profiles, which were acquired as part of a large geophysical on- and offshore experiment, consisting of wide-angle seismic, seismology and magnetotelluric experiments. The line has a total length of $720 \mathrm{~km}, 430 \mathrm{~km}$ along the axis of the Walvis Ridge and $290 \mathrm{~km}$ onshore (Fig. 2). The other four profiles are published in Fromm et al. (2015), Ryberg et al. (2015) and Planert et al. (2017).

\subsection{Acquisition and processing}

Marine wide angle seismic data were acquired with the research vessel Maria S. Merian during the cruise MSM17/2 in January 2011 (Jokat, 2011). The seismic source signal was generated by an $8 \times 81$ G-gun array (64 l or 3905 in. $^{3}$ in total) operated at 200 bar (2900 psi) and $8 \mathrm{~m}$ water depth. In total 27 ocean bottom stations (OBS) and 48 land stations recorded the airgun shots along the presented profile. The OBS had a nominal spacing of approximately $13 \mathrm{~km}$. Occasionally there are larger gaps due to five malfunctioning OBS. A shooting interval of $90 \mathrm{~s}$ resulted in a mean shot point distance of $230 \mathrm{~m}$. The seismic signals were recorded by the OBS at a sampling rate of 200 or $250 \mathrm{~Hz}$ mainly from a hydrophone component and for two stations from a geophone and simultaneously by a $100 \mathrm{~m}$ long, four-channel streamer (Fig. 3).

In addition to the marine source, explosives were used onshore to determine the crustal structure of the continental part of the transect. Eight shots with charges between 250 and $400 \mathrm{~kg}$ were fired at distances between 22 and $45 \mathrm{~km}$. The receiver stations onshore had a mean spacing of $6 \mathrm{~km}$. For logistical reasons the locations of onshore shots and receivers had to follow roads and valleys, which led to an uneven spacing and occasionally large deviations up to $40 \mathrm{~km}$ from the projected profile. 

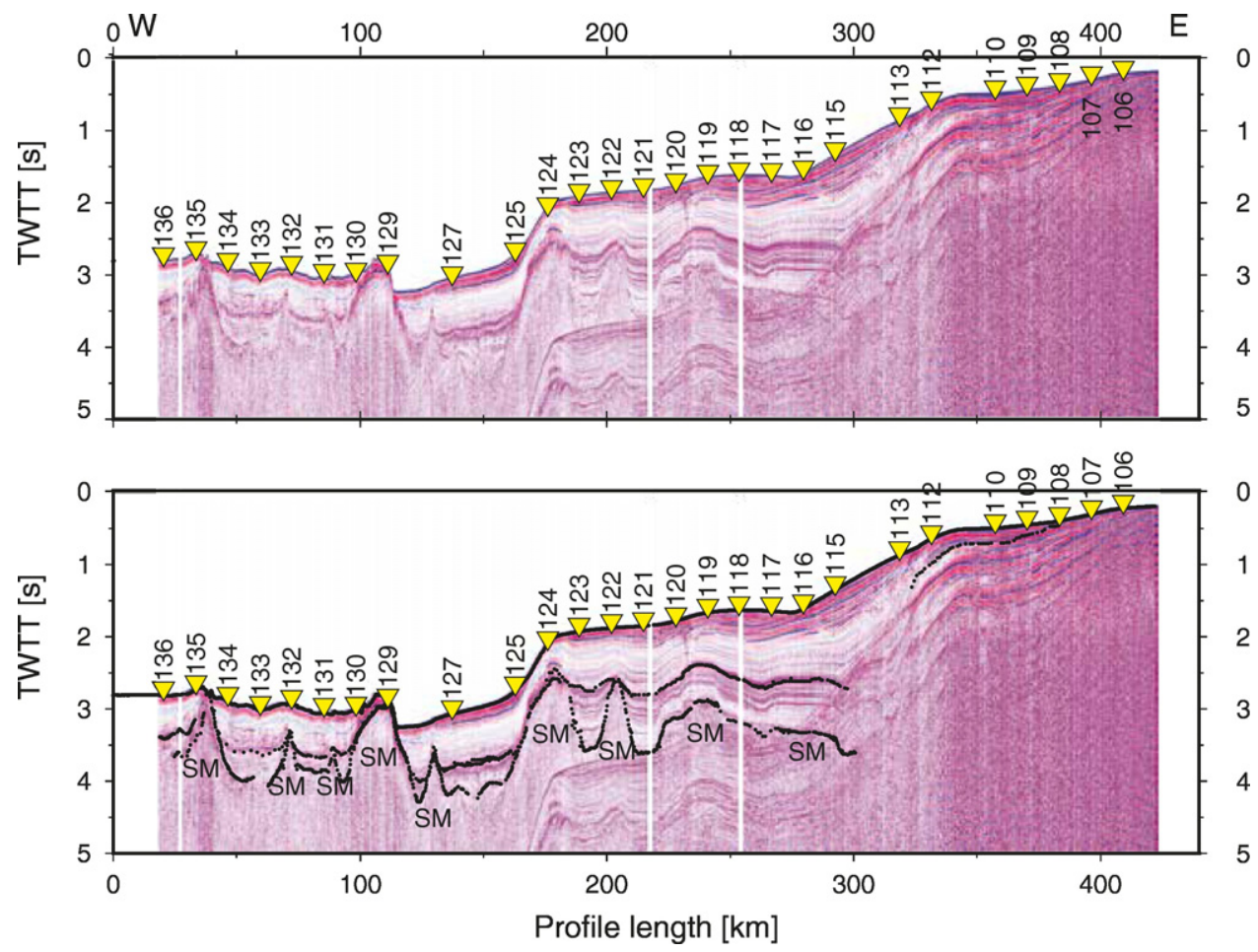

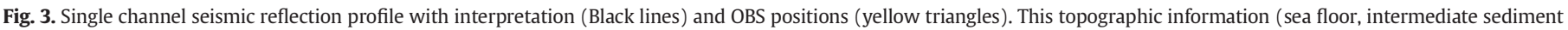

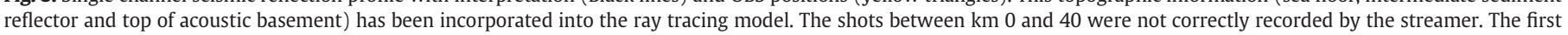
seafloor multiple is strong between $\mathrm{km} 170$ to 430 masking deeper reflections. Multiple seamounts with variable size are revealed along the profile (labelled SM).

The data processing included clock correction, offset calculation and relocation of the OBS. Offsets between shots and receivers were calculated as the shortest distance between their positions. OBS and land stations were arranged in receiver gathers for the airgun shots, while shot gathers were used for the onshore shots. Since currents may shift the OBS while it sinks to the bottom, its exact position at the seafloor is unknown and might slightly differ from the deployment site. This shift can be calculated using the direct arrivals. The first arrival of the source signal resembles a hyperbola with its apex at zero offset if the station location is correct. A hyperbola was fitted and the calculated inline shift was used to correct the offsets. The maximum shift was $130 \mathrm{~m}$. The offline shift is ignored as it affects mainly the near-offset shots and is not important for modelling the crustal structure.

The data quality is highly variable and strongly dependent on the station position and type of source. The OBS show refracted crustal phases (Pg) with maximum offsets varying from 30 to $180 \mathrm{~km}$ (average maximum offset of $60 \mathrm{~km}$ ), with the largest offsets at stations located on basement highs. Reflections from the crust-mantle boundary (PmP phases) are rare and have mostly low signal to noise ratios (Figs. 4 to 6). Phases refracted in the mantle (Pn) could not be observed on the OBS. In contrast, almost all land stations recorded excellent airgun signals with clear Pg and PmP (Fig. 7). Additional Pn phases were observed on most onshore stations with offsets up to $380 \mathrm{~km}$. The dynamite shots recorded on the land stations had an excellent signal to noise ratio for the first arrivals at offsets up to $100 \mathrm{~km}$, but at larger offsets the first and second arrivals (like PmP) were rarely unequivocal (Figs. 8 and 9 ). With the exception of one OBS deployed close to the coast, no seismic signals from dynamite shots could be identified on any OBS records. Figs. 4-9 show several data examples along the line from all different recorder and source types used.

For picking arrivals we used the software ZP (Zelt, 2004). Since the main signal energy was around $6 \mathrm{~Hz}$, we filtered the data with a 3.5$13 \mathrm{~Hz}$ band pass and applied an automatic gain control (AGC) if necessary. Pick uncertainties were manually assigned and ranged between 30 and 250 ms depending on the signal to noise ratio and offsets of phases. Later arrivals generally have larger uncertainties.

\subsection{Modelling}

For creating a 2D velocity model, stations were projected on a straight line, while leaving the source-receiver distances unchanged (Zelt, 1999). The projection was calculated with minimized perpendicular distances for the OBS positions and then extended onshore to cover the land stations. Deviations between OBS locations and the projected profile are small (up to $600 \mathrm{~m}$ ). In contrast, onshore recording stations were up to $40 \mathrm{~km}$ away from the projected line. Hence, the 2D modelling in these areas assume a homogeneous crust up to $40 \mathrm{~km}$ perpendicular to the profile. This is, of course, not the case and larger errors for the crustal model are the consequence. For the marine part of the transect, we used the acquired seismic reflection data (Fig. 3) to extract the depth and topography of the acoustic basement. Since the streamer was too short for a standard velocity analysis, sedimentary velocities were solely calculated from OBS recordings.

Forward modelling was done with the software rayinvr (Zelt and Smith, 1992) following a top to bottom approach by changing velocities and layer depths to fit the observed phase onset and slope. Layer boundaries within the crust are mostly not constrained by reflections and were modelled to account for different velocity gradients (large gradient for the upper crust, small gradient for the lower crust). At some places time gaps occur within the crustal Pg phase, indicating velocity inversions within the crust (Fig. 6). Due to missing refractions at velocity inversions we do not have direct constraints on the velocity for the lower layer. Instead we interpolated the velocity from the neighbouring velocity nodes and then decreased the velocity to obtain a good fit with the observed arrivals. The model was finally inverted with a least square method to optimize the data fit and calculate error statistics (Table 1). The final velocity model is shown in Figs. 10 and 11 and described in detail in section 3. 


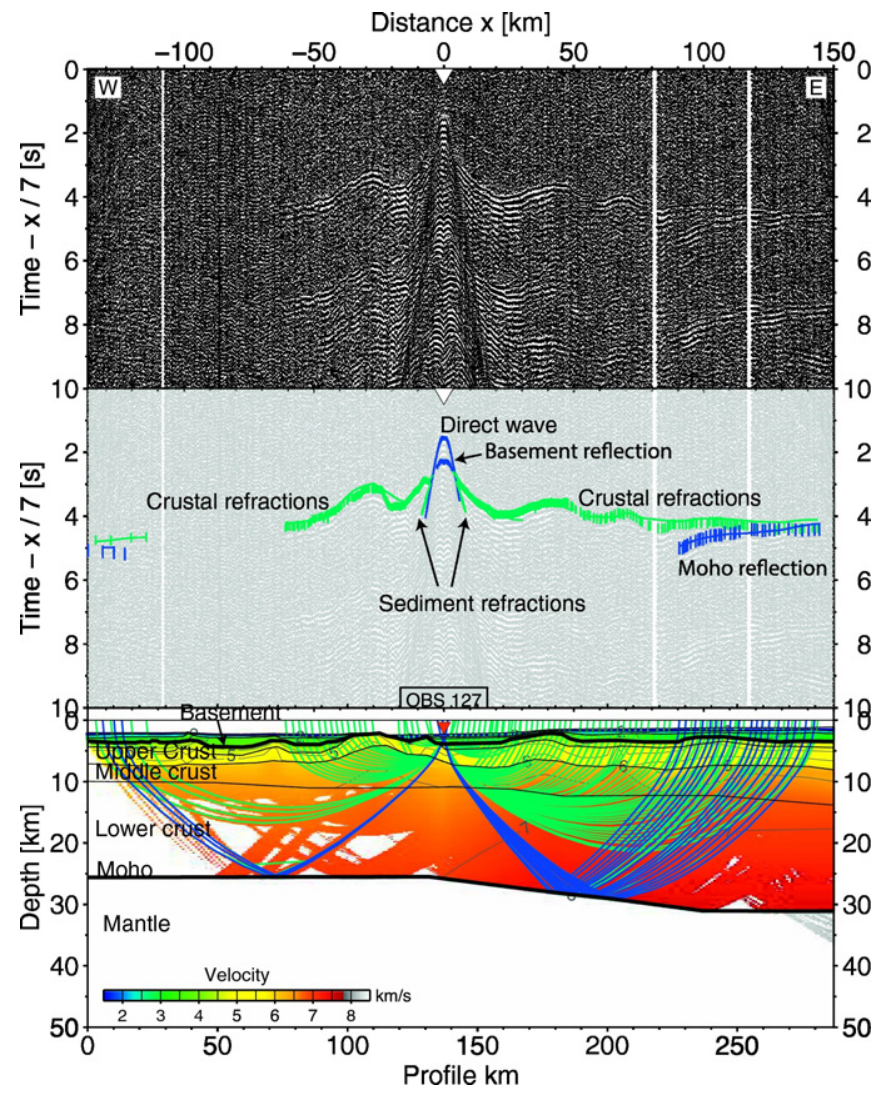

Fig. 4. Data example for recorded seismic data (top), traced arrivals (centre) and ray coverage (bottom) at OBS 127 (hydrophone). This and the following record sections are reduced with $7 \mathrm{~km} / \mathrm{s}$. The data are band-pass filtered with $3.5-13 \mathrm{~Hz}$ corner frequencies and amplified with an automated gain control (AGC) in a $1 \mathrm{~s}$ time window. Picks are vertical bars with variable length representing the pick uncertainty. The number of plotted rays is reduced for clarity. The background shows the colour coded velocity model. White areas indicate parts of the model, which are not covered by any seismic rays. The model layers are drawn in black, selected velocity contours are drawn and annotated in grey. Refracted phases are drawn in green, reflections in blue. The variable basement topography highly influences the travel times. This station is one of the few stations with long offsets of refracted crustal phases and a clear Moho reflection at least to one side of the station and an uncertain reflection to the other.

\subsection{Resolution and model uncertainties}

In total 10,548 picks were traced with an overall travel time residual of $0.115 \mathrm{~s}$, which is in the range of the assumed average pick uncertainties of $0.118 \mathrm{~s}$. The total fit of a model can be judged by the $\chi 2$ value. A value of 1 is targeted and we obtain $\chi 2 \approx 0.73$. For further details, Table 1 summarizes the error estimations for the final model. The resolution plot illustrates spatial resolution of the model and reveals strong variations (Fig. 12). The resolution matrix as well as $\chi 2$ are a mathematical estimation for the error and uncertainty and strongly depend on the distribution and number of model parameters. A better judgement can be made by taking the ray coverage into account (Fig. 13). The ray coverage shows a good cover of shots and reversed shots both for the off- and onshore part of the model. The lowermost crust is generally poorly sampled by refracted phases, but that is commonly seen in crustal models and caused by the low velocity gradient in this layer. Consequently, models have a velocity-depth ambiguity with uncertainties of $\pm 0.2 \mathrm{~km} / \mathrm{s}$ for the lower crust and $\pm 3 \mathrm{~km}$ for the Moho depth. Moho reflections at the coast ( $\mathrm{km} \mathrm{450-500)}$ are only recorded at the land stations. There are no reversed observations from dynamite shots on the OBS recordings. The same applies for the mantle phase (Pn). These model areas are therefore less certain than areas with observations from both sides.

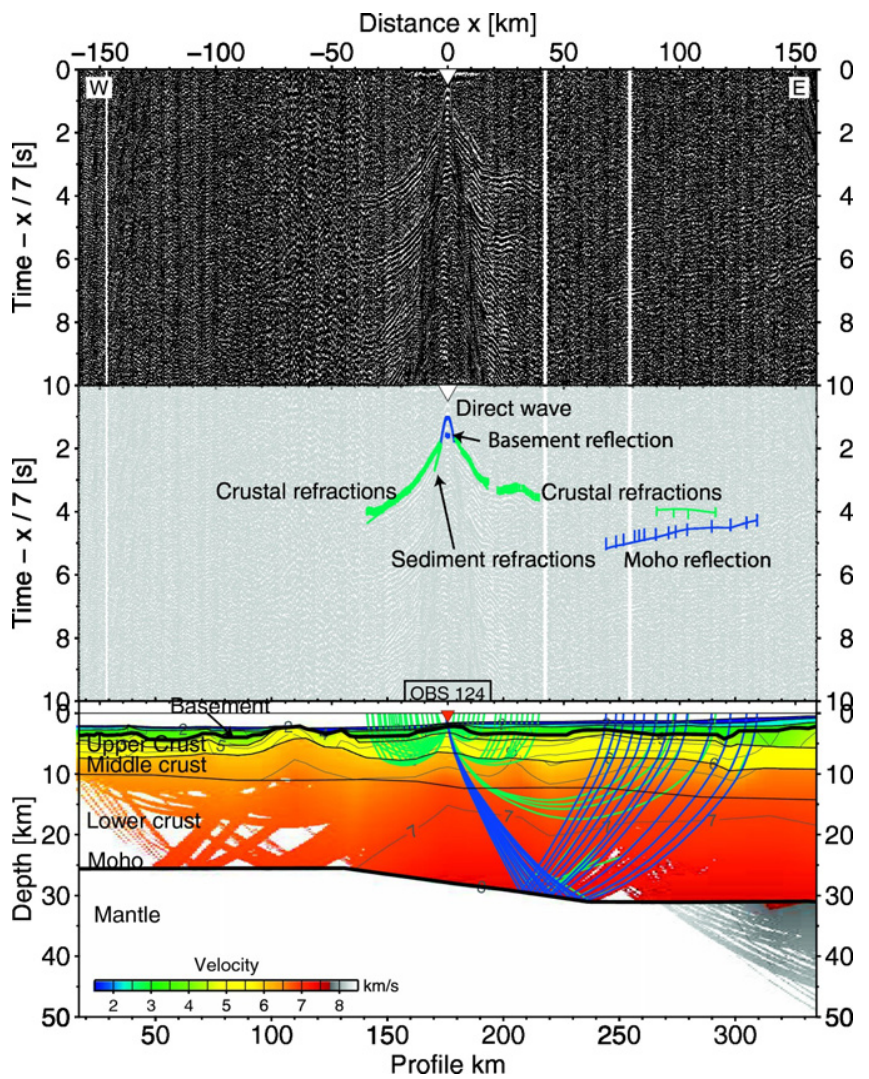

Fig. 5. Recorded seismic data (top), traced arrivals (centre) and ray coverage (bottom) a OBS 124 (hydrophone). Please refer to Fig. 4 for a detailed description of the panel annotation. The highly variable basement topography scatters the signal energy and prevents long offset crustal refractions ( $>60 \mathrm{~km}$ ).

\subsection{Gravity modelling}

After the seismic modelling we conducted a 2D gravity modelling to verify that the crustal structure is consistent with observed gravity anomalies. We used satellite derived free air data for the offshore part of the profile (Sandwell and Smith, 2009) and Bouguer data for the onshore section (Pavlis et al., 2012). The free air anomalies range between -20 and $+60 \mathrm{mGal}$ with various short wavelength undulations. The values for Bouguer anomalies drop from $+20 \mathrm{mGal}$ at the coast to $-110 \mathrm{mGal}$ beneath the Kaoko fold belt before rising to $-100 \mathrm{mGal}$ at the eastern termination of the profile.

We modelled the gravity anomalies with the software IGMAS (Götze and Lahmeyer, 1988). In contrast to the seismic model, an IGMAS model does not consist of layers with variable velocities but of polygons with a fixed density. The initial gravity model was derived from the geometry of the final seismic model and densities that we calculated from the velocities with the empirical Nafe-Drake curve (Ludwig et al., 1970). We kept the model as simple as possible and merged the sediments into one layer. For areas with large lateral variations we divided the seismic layer into smaller polygons. If seismic layers were not constrained by reflections, we allowed the geometry to change for matching the converted density distribution. We finally inverted the model to obtain the best fit between the observed and measured gravity anomalies.

\section{Results and interpretation}

Here, we describe and interpret the velocity model (Figs. 10, 11 and 14). Based on the model structures and velocity depth profiles (Fig. 15), we divide the profile into three sections: (1) thick oceanic crust of Icelandic type in the west ( $\mathrm{km} 0$ to 180 ), (2) a transitional zone, which is 


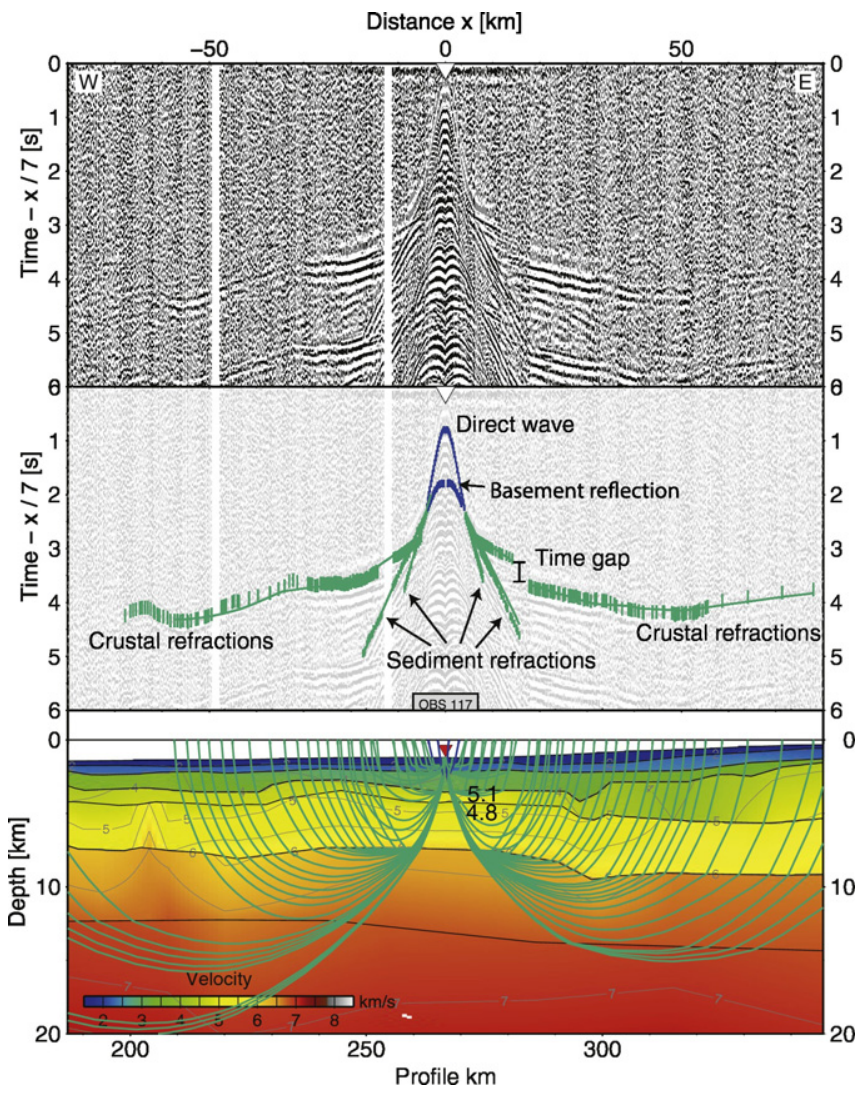

Fig. 6. Recorded seismic data (top), traced arrivals (centre) and ray coverage (bottom) at OBS 117 (hydrophone). Please refer to Fig. 4 for a detailed description of the panel annotation. The upper crustal phases at the east side of the station indicate velocity inversions and strong lateral heterogeneities preventing long offset refractions $(>60 \mathrm{~km})$. Arrivals on the east side do not represent gradients typically seen in oceanic crust.

characterized by intrusions and a high velocity lower crust ( $\mathrm{km} 180$ to 420 ) and (3) a locally intruded, but otherwise unaltered continental crust below the Namibian mainland ( $\mathrm{km} 420$ to 720).

\subsection{Thick oceanic crust ( $k m 0$ to 180 )}

Between $\mathrm{km} 0$ and 170 , the profile has a relative constant water depth of $2000 \mathrm{~m}$ decreasing to $1400 \mathrm{~m}$ at $\mathrm{km} 180$. The sediment cover is up to $2 \mathrm{~km}$ thick, but its thickness is highly variable, due to a number of buried seamounts as revealed in the seismic reflection data (Fig. 3).

Three layers represent the sediments in our model (layer 2, 3 and 4, Fig. 11). The uppermost layer 2 consisting of sediments with high water content cannot be seen in seismic refraction data, but is deducted from ODP sites (Fig. 2, Leg. 40, Site 362, 363, Bolli et al., 1978) and modelled with a velocity of $1.5-1.6 \mathrm{~km} / \mathrm{s}$ and $200 \mathrm{~m}$ thickness. The next layer 3 is $~ 300 \mathrm{~m}$ thick with a velocity of $2.4 \mathrm{~km} / \mathrm{s}$, and is followed by layer 4 with velocities from 3.5 to $3.9 \mathrm{~km} / \mathrm{s}$ (in basement lows up to $1.4 \mathrm{~km}$ thickness), which can be associated with the deepest drilled sediment layer: limestone deposited in the Lower Aptian with velocities of 3.75 to $4.03 \mathrm{~km} / \mathrm{s}$ (Site 362, Bolli et al., 1978). The underlying basement (layer 5) is highly uneven due to numerous seamounts without clear reflections from their flanks, where a mixture of volcanic rocks and clastic material is likely deposited. This reduces the impedance contrast between sediments and igneous crust (Grevemeyer et al., 2001) and hence, the exact thickness of the sediment layers and the upper igneous crust is difficult to determine.

The next three layers 5 to 7 have velocities (4.2-4.8, 4.8-5.8 and 6.1$6.5 \mathrm{~km} / \mathrm{s}$ ) and gradients characteristic for oceanic layer 2 that consists of pillow basalts and sheeted dikes (White et al., 1992). The average

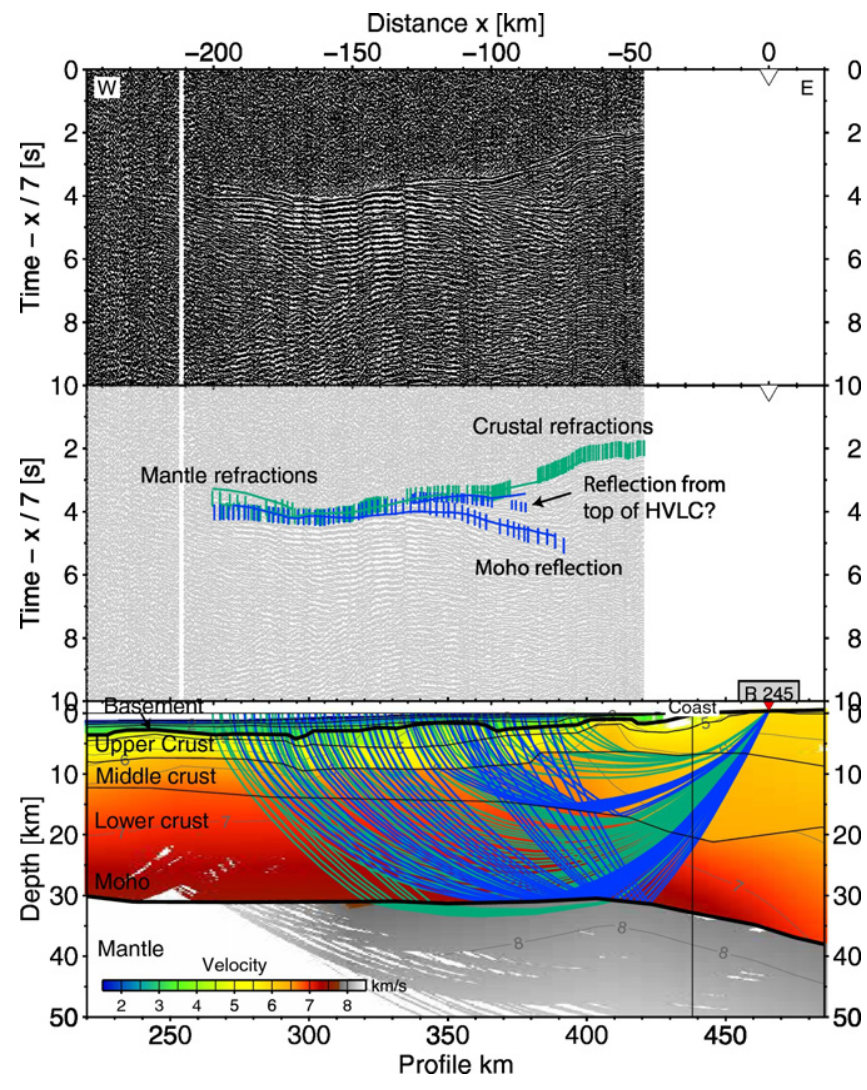

Fig. 7. Recorded seismic data (top), traced arrivals (centre) and ray coverage (bottom) at land receiver 245 (vertical geophone) showing the airgun shots recorded by the land station. Please refer to Fig. 4 for a detailed description of the panel annotation. The data quality is excellent with long offsets up to $200 \mathrm{~km}$ and clear Moho reflections and mantle phases.

thickness for normal oceanic layer 2 is $1.5-2 \mathrm{~km}$ (White et al., 1992); however, along our profile we estimate an anomalous thickness of $6.3 \mathrm{~km}$. That is better described as upper Icelandic-type crust, which corresponds to oceanic layer 2, but has an increased thickness of up to $7 \mathrm{~km}$ with strong lateral and vertical heterogeneities (Foulger et al., 2003). The composition of upper Icelandic-type crust is a combination of lava flows, subsided hyaloclastites and intrusions heterogeneities (Foulger et al., 2003).

The Walvis Ridge lower crust (layer 8 ) is characterized by velocities and gradients typical for the gabbroic oceanic layer $3(6.5-7.2 \mathrm{~km} / \mathrm{s})$, but is likewise unusually thick ( 15.7 instead of $5 \mathrm{~km}$ as reported by White et al., 1992). This is also comparable to Icelandic-type lower crust, which is basically a thick oceanic layer 3 and typically 15 to $30 \mathrm{~km}$ thick (Foulger et al., 2003).

The crust-mantle boundary (Mohorovičić discontinuity or Moho) at $22 \mathrm{~km}$ depth below the basement is only sparsely constrained by reflections (PmP-phases) along our profile. Refracted phases in the upper mantle (layer 9, Pn-phases) are not observed in this part of the profile. A data example illustrating the typical characteristics of this western profile section is shown in Fig. 4. Because of the velocities typical of oceanic crust but with unusual thickness we interpret this section of the profile as thick oceanic crust of Icelandic type.

\subsection{Transitional zone ( $\mathrm{km} 180$ to 420)}

This part of the transect shows distinct differences from the western section (Fig. 10). The most remarkable change is the high velocity lower crust (HVLC), but the upper crust and sediment layers also have different characteristics. Figs. 5 to 7 show data examples for this area. 


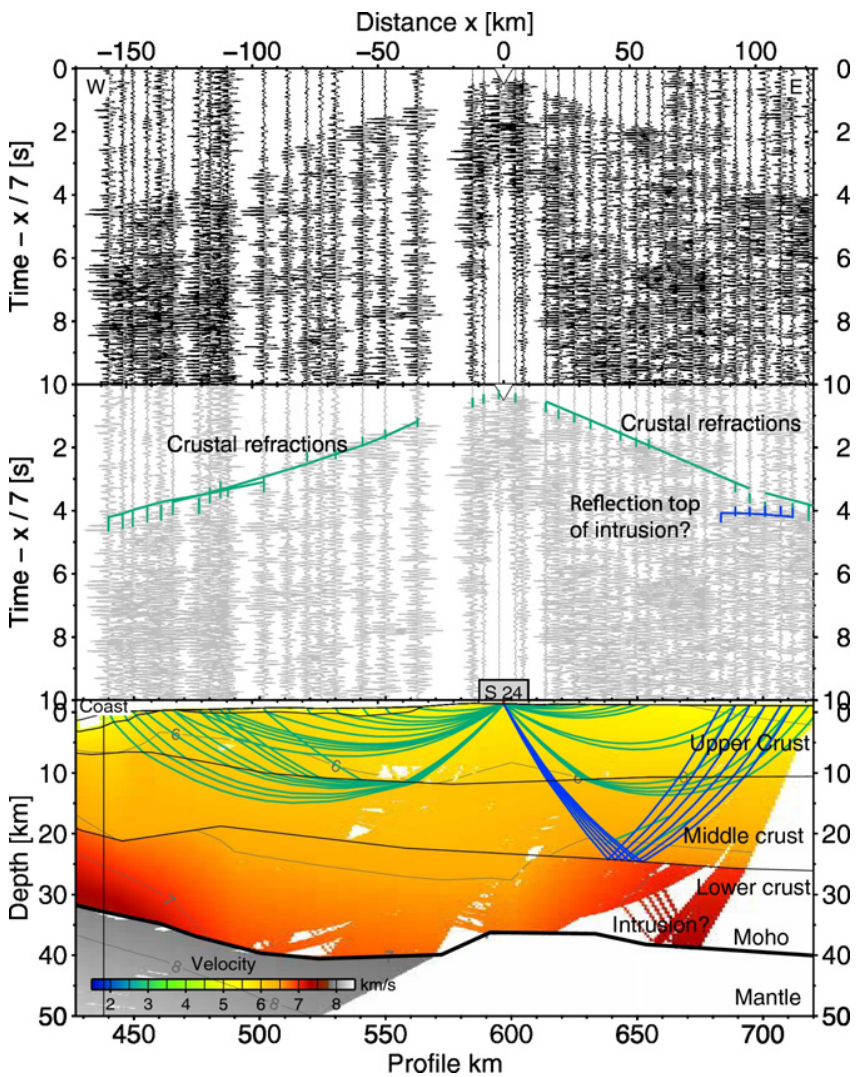

Fig. 8. Recorded seismic data (top), traced arrivals (centre) and ray coverage (bottom) for dynamite shot 24 (Fig. 2). Please refer to Fig. 4 for a detailed description of the panel annotation. This dynamite shot with a charge of $300 \mathrm{~kg}$ was recorded by 48 land receivers (vertical geophones only). A clear reflection on the eastern side has been interpreted as a reflection from the top of an intrusive body. An alternative interpretation as PmP results in a decrease of $\sim 12 \mathrm{~km}$ in crustal thickness, which is inconsistent with gravity data.

The topography changes and water depth decreases in steps from $2000 \mathrm{~m}$ to $140 \mathrm{~m}$ with two relatively level areas at water depths of $1400 \mathrm{~m}$ and $400 \mathrm{~m}$, respectively. The three sediment layers thicken up to $3.0 \mathrm{~km}$ in moats but generally pinch out towards the coast (Fig. 3). Seismic reflection data show more continuous horizons with distinct internal layering and multiple bands of reflectors. The sediment cover on top of the seamounts generally thickens towards the coast. While the western seamounts cut through the sediment layers and occasionally crop out at the seafloor ( $\mathrm{km} \mathrm{40,110),} \mathrm{the} \mathrm{seamounts} \mathrm{east} \mathrm{of} \mathrm{km} 220$ are completely covered by up to $1.5 \mathrm{~km}$ thick, mostly undisturbed sediments. The lower sedimentary layers follow the contours of the underlying basement topography. The shape of the seamounts also changes, becoming flat-topped like guyots (at $\mathrm{km} \mathrm{240,} \mathrm{and} \mathrm{280).} \mathrm{Other} \mathrm{studies}$ (Gladczenko et al., 1998; Elliott et al., 2009) proposed that this part of the Walvis Ridge erupted subaerially or in shallow water (Bolli et al., 1978). Flat-topped guyots form by wave erosion, supporting their assumption.

The seismic velocities of the uppermost part of the crust show much stronger lateral velocity variations $(3.8-5.0 \mathrm{~km} / \mathrm{s}$ ) as in the westernmost part of the transect. In the absence of seismic reflection data it is difficult to interpret these velocity variations. Since it is located in the continentocean transition zone (COT) we might have imaged magmatic structures, strongly intruded continental crust or metasedimentary rock.

In addition, some stations indicate a velocity inversion, expressed in a discrete time gap of the first arrivals (Fig. 6). Those areas are laterally confined to narrow zones and no reflections constrain velocities or the layer thickness for these areas. They might be caused by lava flows (with high velocities $5.3 \mathrm{~km} / \mathrm{s}$ ) covering older sediment layers or hyaloclastic material with lower seismic velocities. Such lava flows

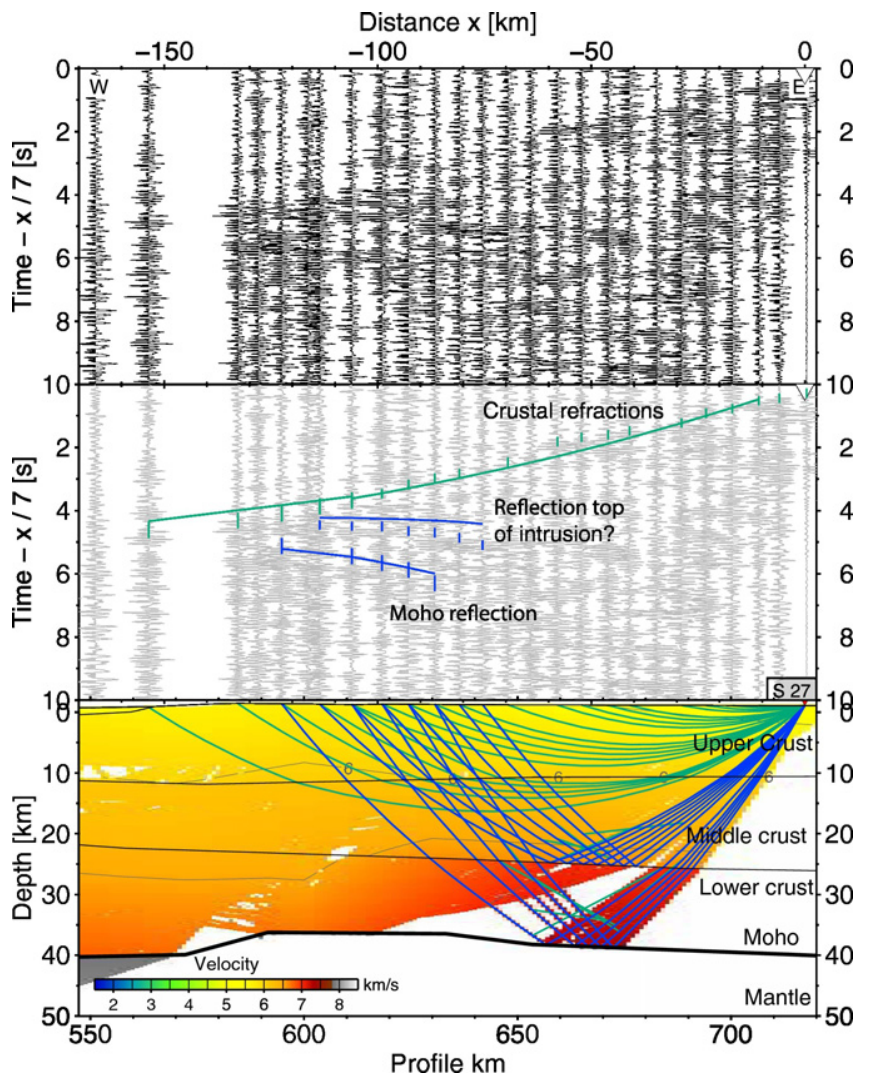

Fig. 9. Recorded seismic data (top), traced arrivals (centre) and ray coverage (bottom) for dynamite shot 27 (Fig. 2). Please refer to Fig. 4 for a detailed description of the panel annotation. This dynamite shot with a charge of $300 \mathrm{~kg}$ was also recorded by 48 land receivers (vertical geophones only). This record section displays two deep reflections, which are interpreted as reflections from the top of an intrusive body and the Moho.

and velocity inversions have also been detected at a seismic profile crossing the Walvis Ridge in N-S direction (Fig. 2, Planert et al., 2017).

Velocities of the lower crust are higher than in the western part of the profile (up to $7.5 \mathrm{~km}$ ). Those high velocities are not directly constrained by refracted phases, as refractions usually do not reach the lowest part of the lower crust, due to the low gradient. But the slopes of the first arrivals in this area indicate higher velocities than in the westernmost part of the profile ( 7.2 compared to $7.0 \mathrm{~km} / \mathrm{s}$ ). The Moho topography is flat and does not mirror the rough basement topography with its numerous seamounts. Upper mantle velocities of $7.9 \mathrm{~km}$

\section{Table 1}

Error statistics showing the phase number, number of travel time picks (n), RMS error (trms) and normalized $\chi 2$. The first digit of the phase resembles the layer, the second digit the ray type $(1=$ refraction, $2=$ reflection, $3=$ head wave).

\begin{tabular}{lllll}
\hline Phase & $\mathrm{n}$ & trms/s & $\chi 2$ & Comment \\
\hline 22 & 46 & 0.071 & 1.061 & Sediment reflection \\
31 & 752 & 0.057 & 0.667 & Sediment refraction \\
32 & 165 & 0.072 & 1.056 & Sediment reflection \\
41 & 982 & 0.061 & 0.756 & Sediment refraction \\
42 & 141 & 0.084 & 1.464 & Basement reflection \\
51 & 1475 & 0.058 & 0.332 & Upper crustal refraction \\
52 & 112 & 0.128 & 1.645 & Upper crustal reflection \\
61 & 2028 & 0.097 & 0.818 & Upper crustal refraction \\
62 & 9 & 0.074 & 0.396 & Mid crustal reflection \\
71 & 2893 & 0.096 & 0.505 & Mid crustal refraction \\
72 & 38 & 0.234 & 2.503 & Reflection top of intrusion/HVLC \\
81 & 921 & 0.163 & 1.085 & Lower crustal refraction \\
82 & 798 & 0.218 & 1.098 & Moho reflection (PmP) \\
83 & 10 & 0.405 & 4.562 & Mantle head wave \\
91 & 178 & 0.264 & 1.121 & Mantle refraction (Pn) \\
Total & 10,548 & 0.115 & 0.727 & \\
\hline
\end{tabular}




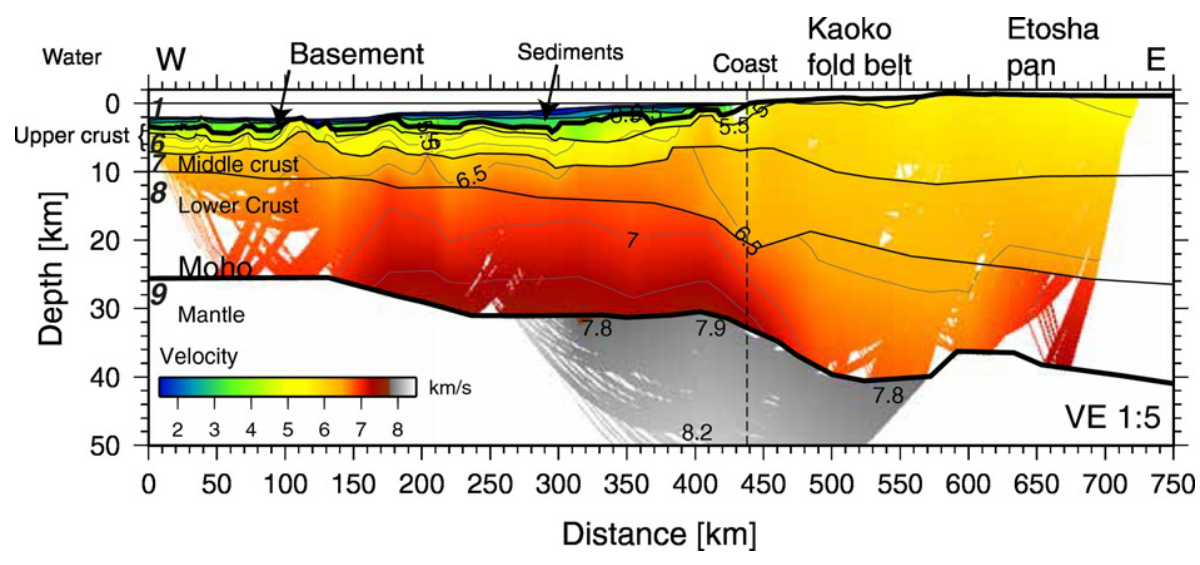

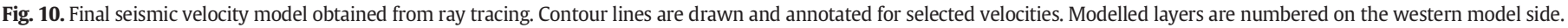
White areas indicate part of the model, which are not covered by any seismic rays.

are mainly based on Pn phases observed on the land stations, which recorded the airgun shots at offsets well beyond $200 \mathrm{~km}$.

Lower crustal velocities above $7.0 \mathrm{~km} / \mathrm{s}$ are considered as unusually high and do not appear in normal oceanic crust (White and McKenzie, 1989). We therefore define parts of the lower crust with velocities above $7.0 \mathrm{~km} / \mathrm{s}$ as a high velocity lower crust (HVLC). The top of the HVLC is not bounded by reflections along this profile. There is only one intra-crustal reflection at $\mathrm{km} \mathrm{430,} \mathrm{though} \mathrm{the} \mathrm{reflector} \mathrm{is} \mathrm{shallower}$ than the $7.0 \mathrm{~km} / \mathrm{s}$ contour line and cannot unambiguously be linked with the upper boundary of the HVLC as there are not enough observations. However, Planert et al. (2017) observed reflections from the upper boundary on a N-S profile across the Walvis Ridge (Fig. 2). The HVLC extends $330 \mathrm{~km}$ along our line (Fig. 14, km 140-470), is $12 \mathrm{~km}$ thick and the crystalline crust thickens to $28 \mathrm{~km}$. Other studies also found such HVLC south of the Walvis Ridge (Bauer et al., 2000; Schinkel, 2006; Hirsch et al., 2009; Becker et al., 2014). Here, the lower crustal velocities range between 7.6 and $7.4 \mathrm{~km} / \mathrm{s}$, respectively. The nature, petrology and evolution of these HVLCs, in general, are still debated. They appear along volcanic passive margins in the COT and have been interpreted as accreted mafic material underplating stretched, rifted and heavily intruded continental crust (White et al., 1987) or as intrusions of igneous sills in continental crust without an accreted underplating (White et al., 2008). Opposing those interpretations, which require the presence continental crust, Bauer et al. (2000) suggest that the transitional zone and the HVLC are entirely composed of igneous material. HVLCs have also been observed independent from continental margins at oceanic plateaus and hot spot tracks. There, they might be explained with fractionated cumulates from picritic mantle melts (Farnetani et al., 1996).

A clear interpretation of the origin of the high-velocity lower crust and an exact location of the continent-ocean boundary (COB) based on our P-wave velocity model is difficult because of the strong lateral variations in velocities and gradients in the upper and middle crust, abundant seamounts and the high velocities in the lower crust. Never-

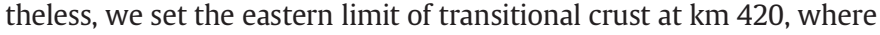
we observe the first indications of a large magmatic intrusion reaching into the upper crust.

We interpret this section as the transition between continental and thick oceanic crust of Icelandic type. It is highly affected by volcanism, but intruded continental blocks might still be present.

\subsection{Continental crust ( $\mathrm{km} 420$ to 720 )}

Between $\mathrm{km} 420$ and $\mathrm{km} 460$ the seismic velocities decrease from 6.1 to $5.9 \mathrm{~km} / \mathrm{s}$ in the upper crust and from 6.4 to $6.1 \mathrm{~km} / \mathrm{s}$ in the middle crust, which are typical velocities for continental crust (Christensen and Mooney, 1995, Figs. 10 and 15). The HVLC stretches eastwards approx. $30 \mathrm{~km}$ into the continental crust before it terminates and velocities decrease to normal values for lower continental crust $(6.9 \mathrm{~km} / \mathrm{s}$, Christensen and Mooney, 1995). The eastern termination of this HVLC roughly coincides with the seaward edge of the Kaoko fold belt. The crust-mantle boundary at $40 \mathrm{~km}$ beneath the Kaoko fold belt at $\mathrm{km}$ 530 is at a similar depth as further south in the Damara fold belt of similar age (Bauer et al., 2000, for location refer to Fig. 2), and it decreases to

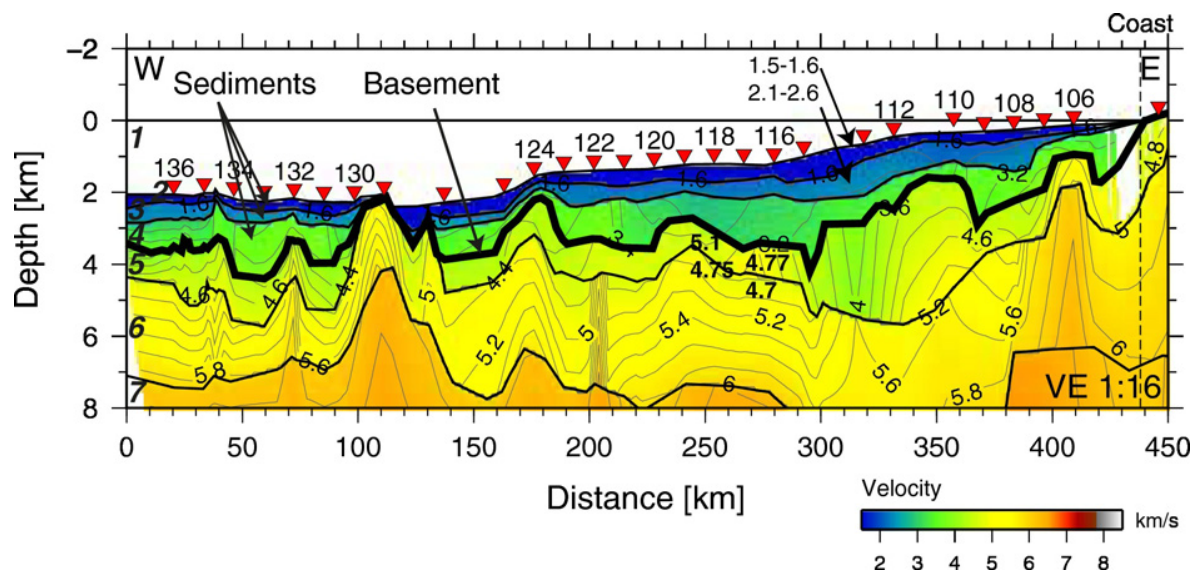

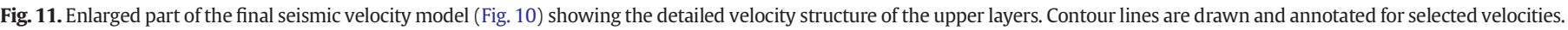

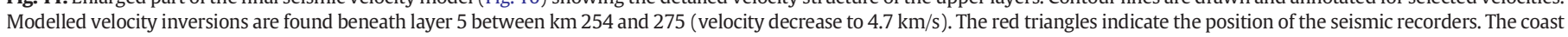
line is marked by a dashed vertical line at $\mathrm{km} 440$. 


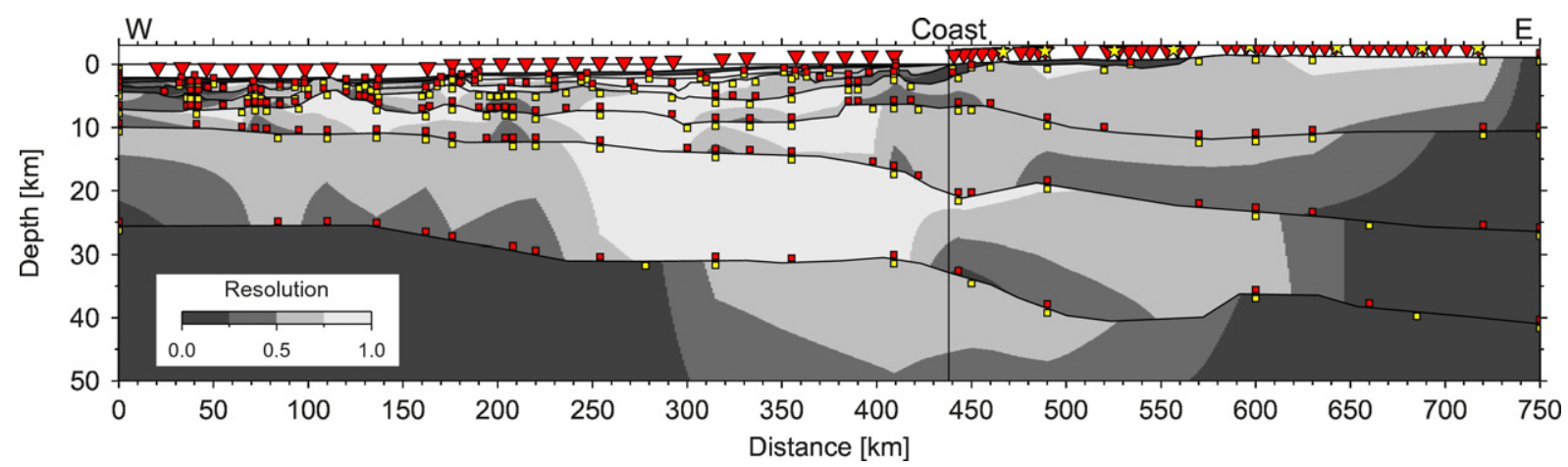

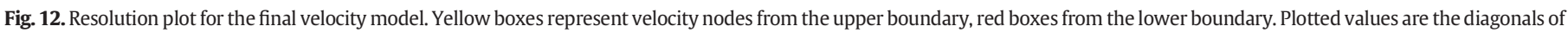
resolution matrix and range between 0 and 1. Nodes with values larger than 0.5 are considered as well resolved (Zelt and Smith, 1992; Lutter et al., 1990).

$36 \mathrm{~km}$ at $\mathrm{km}$ 610, where the Kaoko belt borders on the plains of Etosha. Further east, at km 650, we added a high velocity body in the lower crust. This area of the profile is not well constrained and the interpretation of travel time arrivals is ambiguous. We observe reflections from a shallow reflector at approx. $25 \mathrm{~km}$ depth at two stations (st. 24, 27), which are in conflict with reflections from other stations (st. 22, 23) covering the same area. Gravity modelling (Fig. 16) indicates that there is an intrusive, high density body within the crust and we interpret the shallow reflections to originate from the top of this intrusion and not from the Moho. The slight decrease in crustal thickness landwards of the Kaoko fold belt is confirmed by another seismic profile (Planert et al., 2017, for its location see Fig. 2) and seismological data (Heit et al., 2015). We interpret the thicker crust under the Kaoko belt as the crustal root of the fold belt.

In this part of the transect, we observe only a small section with unusually high velocities in the lower crust. Large-scale intrusions or rifted and thinned continental crust are absent or beyond resolution. Instead, the crust remains mainly undisturbed and the crustal root of the Kaoko fold belt is not affected by the hot mantle material.

\section{Results from gravity modelling}

Here, we describe the results of the gravity modelling based on the converted seismic model. (Fig. 16). The free air anomalies are dominated by short frequency variations, which are in general well matched and originate in the buried basement topography. The large drop in the Bouguer values from $0 \mathrm{mGal}$ at $\mathrm{km} 430$ to $-110 \mathrm{mGal}$ at $\mathrm{km} 600$ is well matched and caused by the generally lower density of continental crust.

Between $\mathrm{km} 0$ and 70, the calculated gravity anomalies are around 10 to $30 \mathrm{mGal}$ too low but the short wavelength variations are reasonably well matched. There are strong gravity anomalies north and south of the profile, which likely have a large 3D effect on the model. Goslin and Sibuet (1975) analysed sonobuoy profiles crossing our line perpendicular and modelled thicker crust north and south of our line with a thinner crust the profile intersection. With these three-dimensional variations in mind we consider this miss match acceptable.

Larger deviations of 20 to $50 \mathrm{mGal}$ in the short wavelength between the modelled and observed gravity data occurred in the region of continent-ocean transition from $\mathrm{km} 320$ to 470 (Fig. 16). We attribute these deviations to side effects of the highly three-dimensional structure of the Walvis Ridge. Specially, near the coast there are two gravity anomalies of 80 and $40 \mathrm{mGal}$ north of the seismic profile (Fig. 17), which likely have an influence on the measured gravity along the profile but are not observed in the seismic data. The largest deviation is at the coast between $\mathrm{km} 425$ to 475 . Here, the measured and calculated gravity differs as much as $50 \mathrm{mGal}$. This region is one of the more difficult regions to seismically image with our experimental setup, but is also a crucial area for tectonic interpretation, particularly how far east the HVLC extends, and what its relation to the continental crust is. Interestingly,

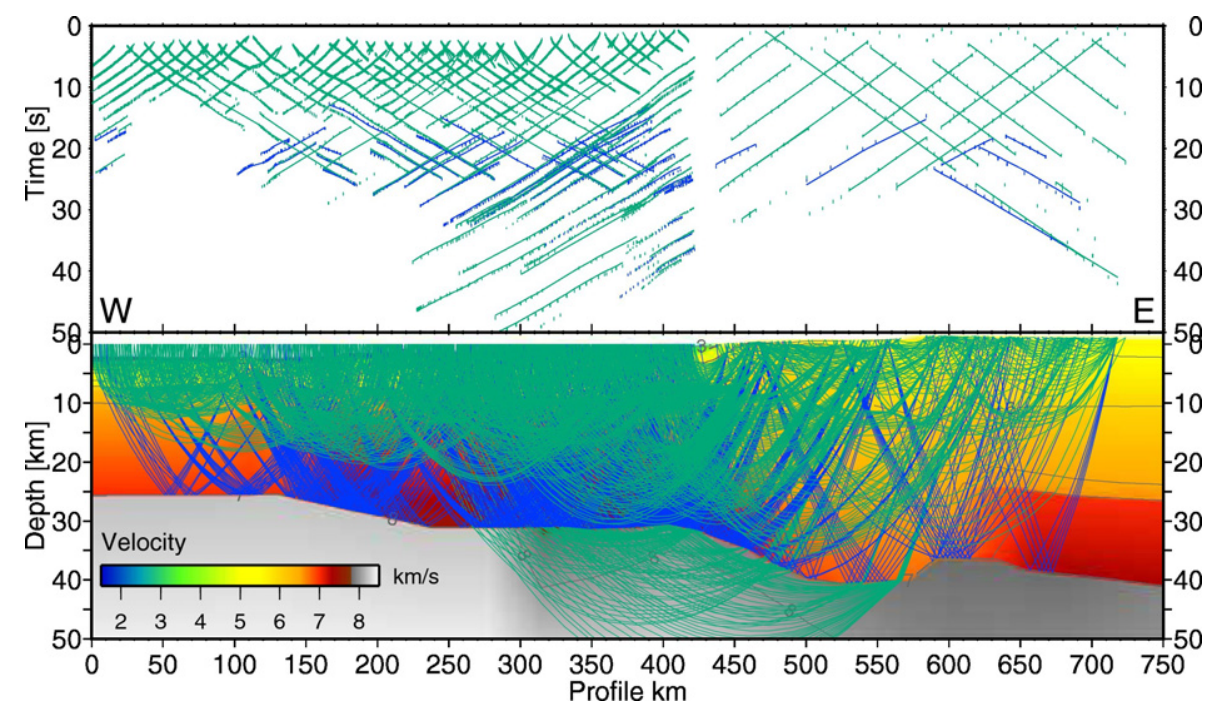

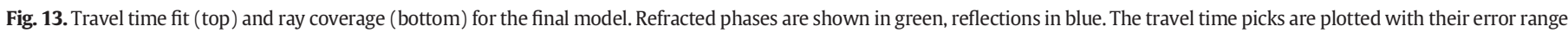
as bars. The ray coverage is a good estimate for the quality of a model and reveals poorly sampled areas, e.g. the velocities at the base of the lower crust. 


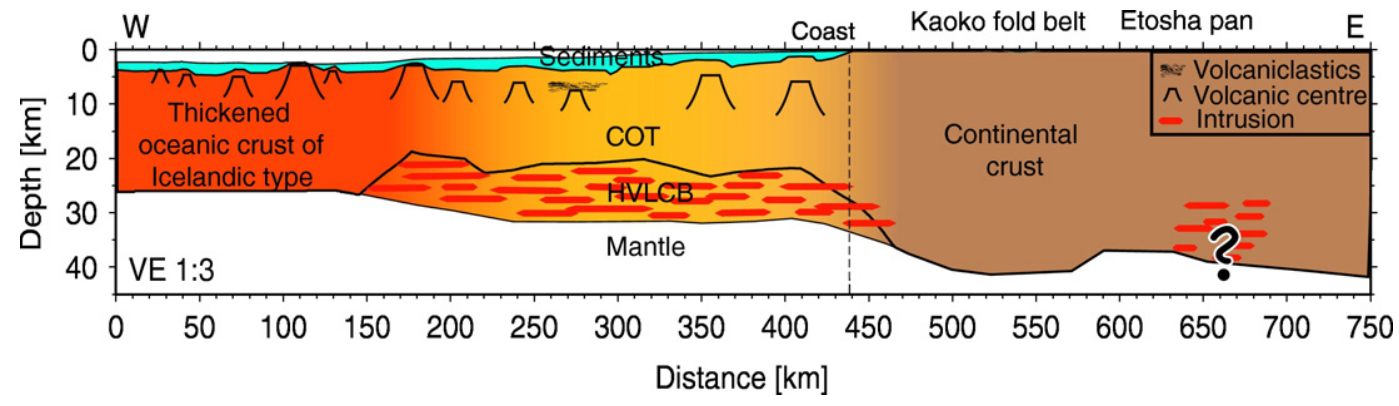

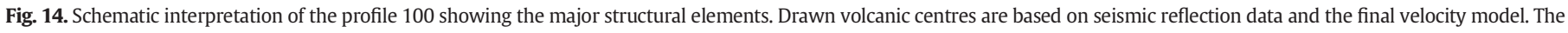
blue layer summarizes sedimentary layers. Abbreviations: COT - continent-ocean transition, HVLC - High Velocity Lower Crust.

we cannot determine the extent of the high-density body from the free air anomalies. There is no significant drop in the anomaly level at its seaor landward termination. We have tested different models with and without a high density body in the lower crust but none could match the measured short frequency gravity anomalies in this area. Instead, a model with a low-density body in the upper crust matches the observed gravity very well. The existence of such a shallow low-density body is reasonable, because there is a large area of sand dunes parallel to the coast. Sand has a much lower density than crystalline rocks, 1.5$1.75 \mathrm{~g} / \mathrm{cm}^{3}$ compared to $2.6-2.9 \mathrm{~g} / \mathrm{cm}^{3}$ (Luo et al., 2011; Christensen and Mooney, 1995) and the areal extend of the dune field matches the geometry of the coast parallel gravity minimum (Fig. 17). However, lacking constraints for the thickness and density of such a body from seismic data, we believe that a well-matched model in this problematic region would not be very meaningful geologically.

There was a major mismatch between the seismic and the gravity model at the eastward end of the profile at km 600-650. Here, the initial velocity model showed a decrease in crustal thickness, which was inconsistent with our gravity modelling. We therefore reviewed the seismic model and introduced an intrusive crustal body instead of a $\sim 12 \mathrm{~km}$

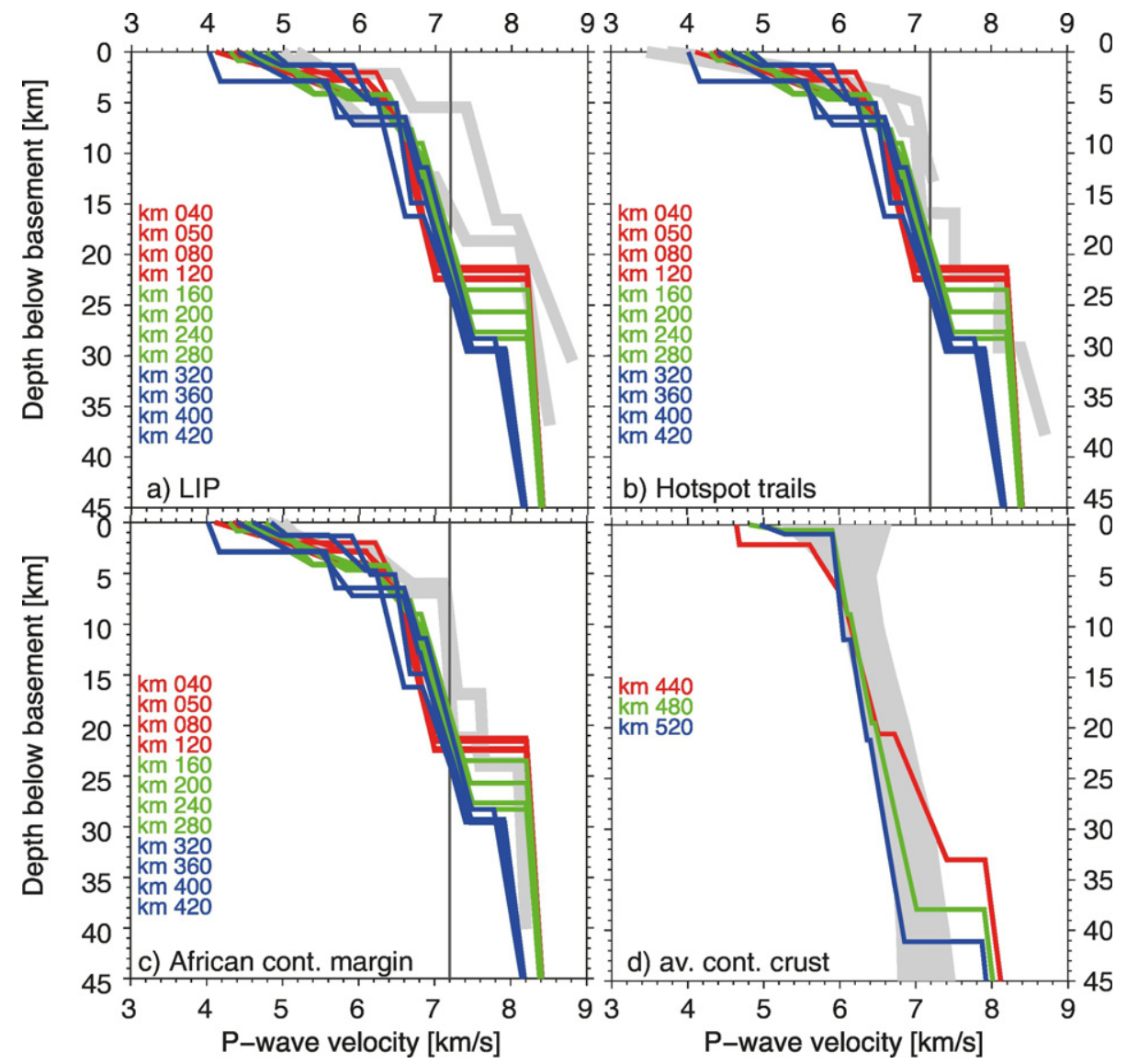

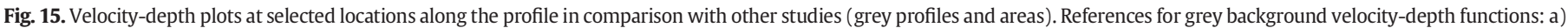

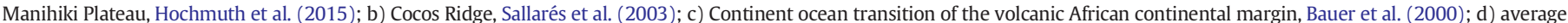

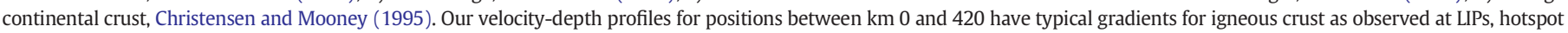

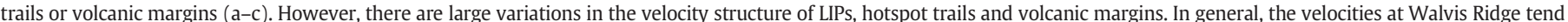

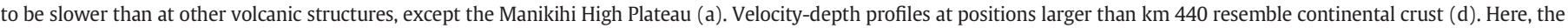

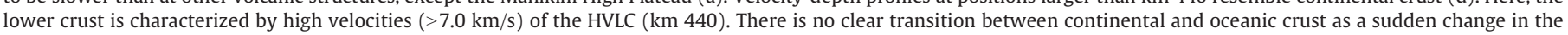
velocity-depth profiles visible. 
a)

$\mathrm{km}$

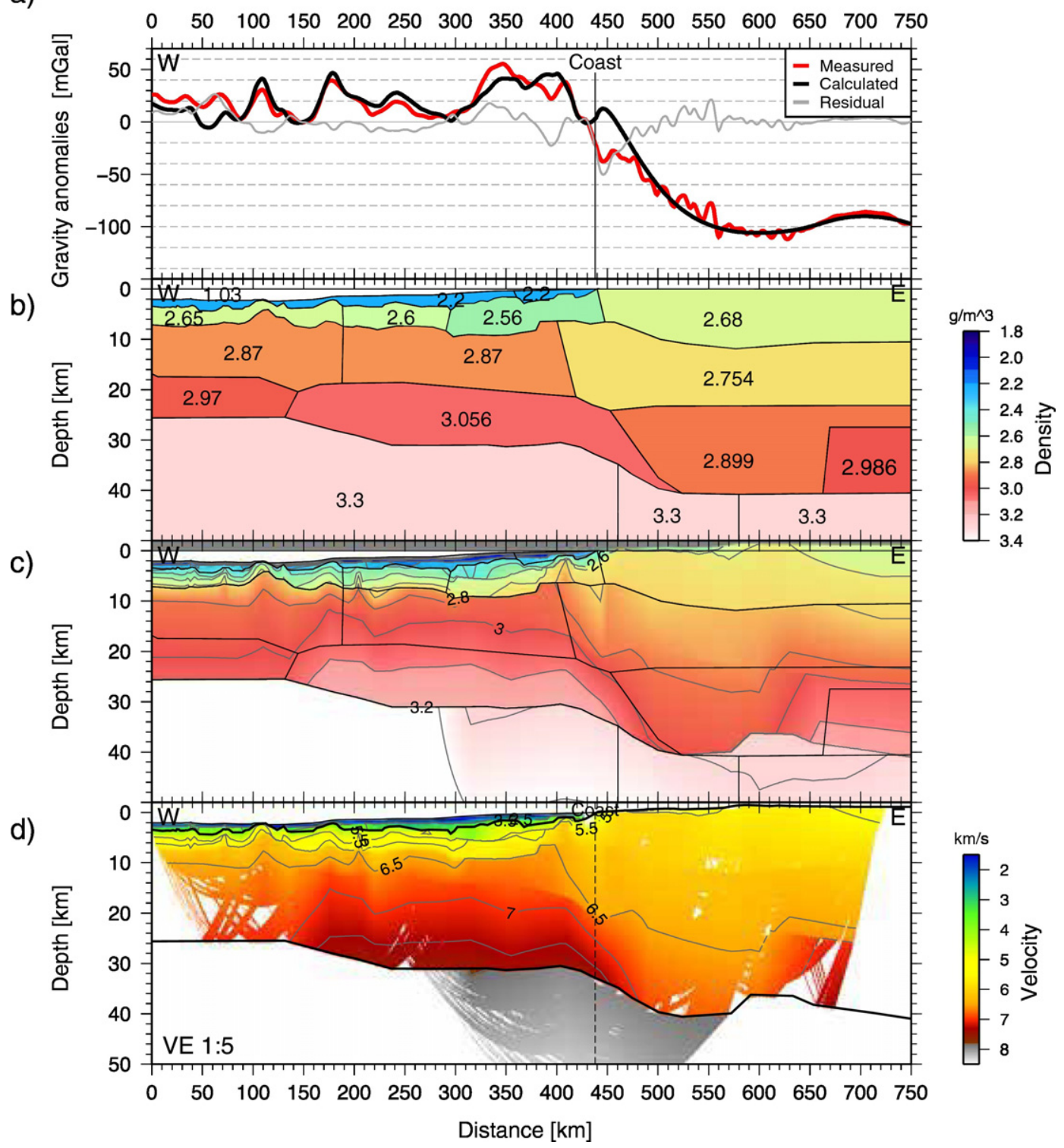

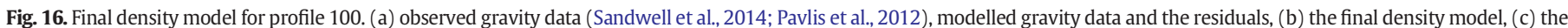

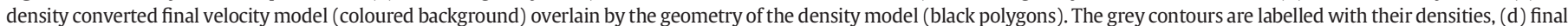
seismic P-wave velocity model.

decrease in crustal thickness. Consequently the reflected phases, which we initially interpreted to indicate a crustal thinning, most likely originate from the top of a lower crustal intrusive body.

\section{Discussion}

Our study provides a detailed insight into the deep crustal structure along the axis of the Walvis Ridge, and the adjacent African continent. The Walvis Ridge has long been interpreted as a hotspot track (Morgan, 1971). In detail, though, while the bathymetry of its western part can easily be interpreted in terms of a volcanic lineament or seamount province, the origin of the massive eastern Walvis Ridge close to the Namibian coast and the nature/position of the continent-ocean transition and boundary are still debated. The position of the COB is used for paleogeographic and plate kinematic reconstructions of the South Atlantic. A better understanding of the eastern Walvis Ridge crust and upper mantle can also constrain processes driving continental breakup, e.g. how severe the proposed plume impact/thermal anomaly modified the continental crust.

\subsection{The crustal composition of the eastern Walvis Ridge}

Our data and model (Fig. 10) show that the massive bathymetric feature of the eastern Walvis Ridge consists of thick oceanic crust of Icelandic type and seamounts buried under thick sediments.

Comparing the crustal structure of our profile with other aseismic ridges is difficult because of the profile orientation. Our profile extends along the ridge axis, but most wide-angle seismic profiles of similar experiments perpendicularly cross the structures and, thus, do not image variations along the ridge axes, which we identified. To our knowledge the only analogous region to the Walvis Ridge at which wide-angle seismic profiles have been acquired along the ridge axis is the junction of the Iceland-Faroe Ridge with the continental Faroe Islands (Richardson et al., 1998). Unlike in our profile, there is no evidence of individual volcanic centres and the whole ridge has a more homogeneously layered structure. This difference might be explained with the different levels of magmatic activity. High melt supply causes fissure eruptions while low melt supply causes point source eruptions (Behn et al., 2004). The Tristan hotspot is less productive than the Iceland hotspot (Gallagher and 

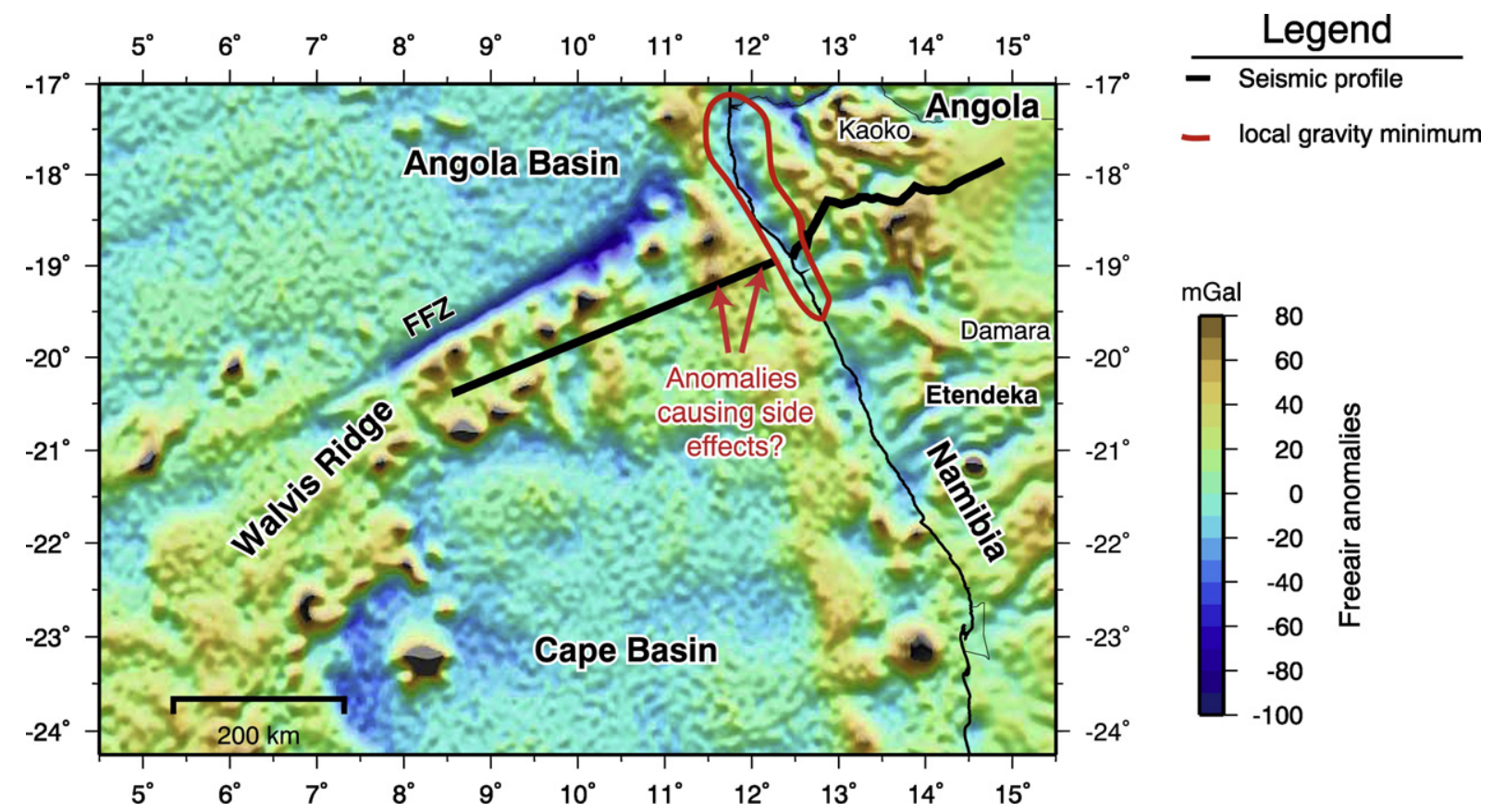

Fig. 17. Free air gravity map (Sandwell et al., 2014) of the research area together with the position of profile 100 (thick black line).

Hawkesworth, 1994; Ito et al., 1996) and therefore might have produced distinct volcanic centres instead of a massive single body.

There are various interpretations of the location of the $\mathrm{COB}$ at the Walvis Ridge based on different datasets. A location of the COB defined as the onset of magnetic spreading anomalies and an anomalous gravity high (Rabinowitz and LaBrecque, 1979) is not possible because of the absence of sufficient data to show such magnetic lineation (if existent) and a clear gravity high on the ridge. Previous interpretations of seismic reflection data are not consistent in their interpretation of a COB based on rift structures (Sibuet et al., 1984; Gladczenko et al., 1998) and a considerable amount of continental crust was suspected at the eastern Walvis Ridge (Sibuet et al., 1984). Given the geological framework with the superimposed effects of hotspot volcanism and rifting, it is not surprising that our data do not show a clear COB based on changes in the crustal velocities. Massive volcanism affects the crust of the eastern Walvis Ridge and produced strong lateral variations overprinting rifting effects. However, the data reveal a $240 \mathrm{~km}$ wide COT with increased crustal thickness, surface volcanism and high velocities in the lower crust. The suggested COB locations of other studies (Sibuet et al., 1984; Gladczenko et al., 1998) fall within this range. Here, continental crust might be partially present but based on the amount of volcanic features and velocities typical for basaltic material we interpret this transitional zone to consist mainly of igneous material. Similar results with thick igneous crust forming the COT were found south of the Walvis Ridge along the continental margin (Fig. 18, Bauer et al., 2000; Schinkel, 2006; Hirsch et al., 2009). The onset of oceanic, or thick oceanic crust of Icelandic type in case of the Walvis Ridge, is at approximately the same distance from shore for all profiles. Besides the disagreement on the location of a COB, Eagles et al. (2015) recently challenged the concept of $\mathrm{COBs}$ in general. The large uncertainties involved in defining the COB makes it of little use in plate kinematic reconstructions even though the COB is still invoked (Eagles et al., 2015).

\subsection{Indications for a plume head?}

The most important feature of our velocity model for the evolution of the Walvis Ridge is the high velocity lower crust with velocities up to $7.5 \mathrm{~km} / \mathrm{s}, 12 \mathrm{~km}$ thickness and $330 \mathrm{~km}$ width (HVLC, Fig. 10). Here we discuss its origin as part of a large igneous province, implications for plume models and continental breakup.

High seismic velocities in the lower crust and SDRs (seaward dipping reflectors) are typical of volcanic margins and have been observed along both South Atlantic conjugate margins south of the Walvis Ridge (e.g. Becker et al., 2014, and references therein). Together with the continental flood basalts of Paraná and Etendeka they form a large igneous province (LIP), characterized by the emplacement of a large magma volume within a short period of time $\left(>0.1 \cdot 106 \mathrm{~km}^{2}\right.$ within $1-5 \mathrm{Ma}$, Bryan and Ferrari, 2013). In general, LIPs are considered to be the products of melt that is supplied from a deep thermal mantle plume. Geophysical data support this model for oceanic LIPs, but the presence and extent of HVLC under continental flood basalts is arbitrary. While the Columbia River, Deccan and Siberian flood basalts all appear to be underlain by high velocity $(6.9-7.5 \mathrm{~km} / \mathrm{s})$ bodies, the Emeishan flood basalts seems to be underlain only in its centre and lack fast lower crust at their rims (Ridley and Richards, 2010). The spatial extent of plume-derived magmatism is proposed to mimic the plume head at the base of the lithosphere across a large area. Based on the distribution of surface volcanism, White et al. (1987) estimated a diameter of 1000-2000 km for a plume head, while laboratory experiments and modelling of Griffiths and Campbell (1990) suggested 2000-2500 km. Theoretical analysis based on mantle heat flux and viscosity led Tan et al. (2011) to calculate that the flattened plume might affect the lithosphere over a distance of 1173-1842 km centred on the plume conduit. However, such large structures have never been detected in seismic tomography of the lithosphere-asthenosphere boundary. This is just one of the reasons why the deep plume model is controversial. Another class of models associates some or all hotspot volcanism with decompression melting (Raddick et al., 2002), stress release (Fairhead and Wilson, 2005; Elliott et al., 2009) or small-scale mantle convection (King and Ritsema, 2000), implying that the magmatism is fed by shallow sources.

According to the plume model the eastern Walvis Ridge is at a key position, linking the first appearance of the plume tail derived seamount chain to the plume head related continental flood basalts. This special location right above the proposed conduit sets the Walvis Ridge apart from the rest of the continental margin and makes it ideal to investigate the effect of the proposed plume head. In this context, the most remarkable difference between our profile and profiles south of the Walvis 

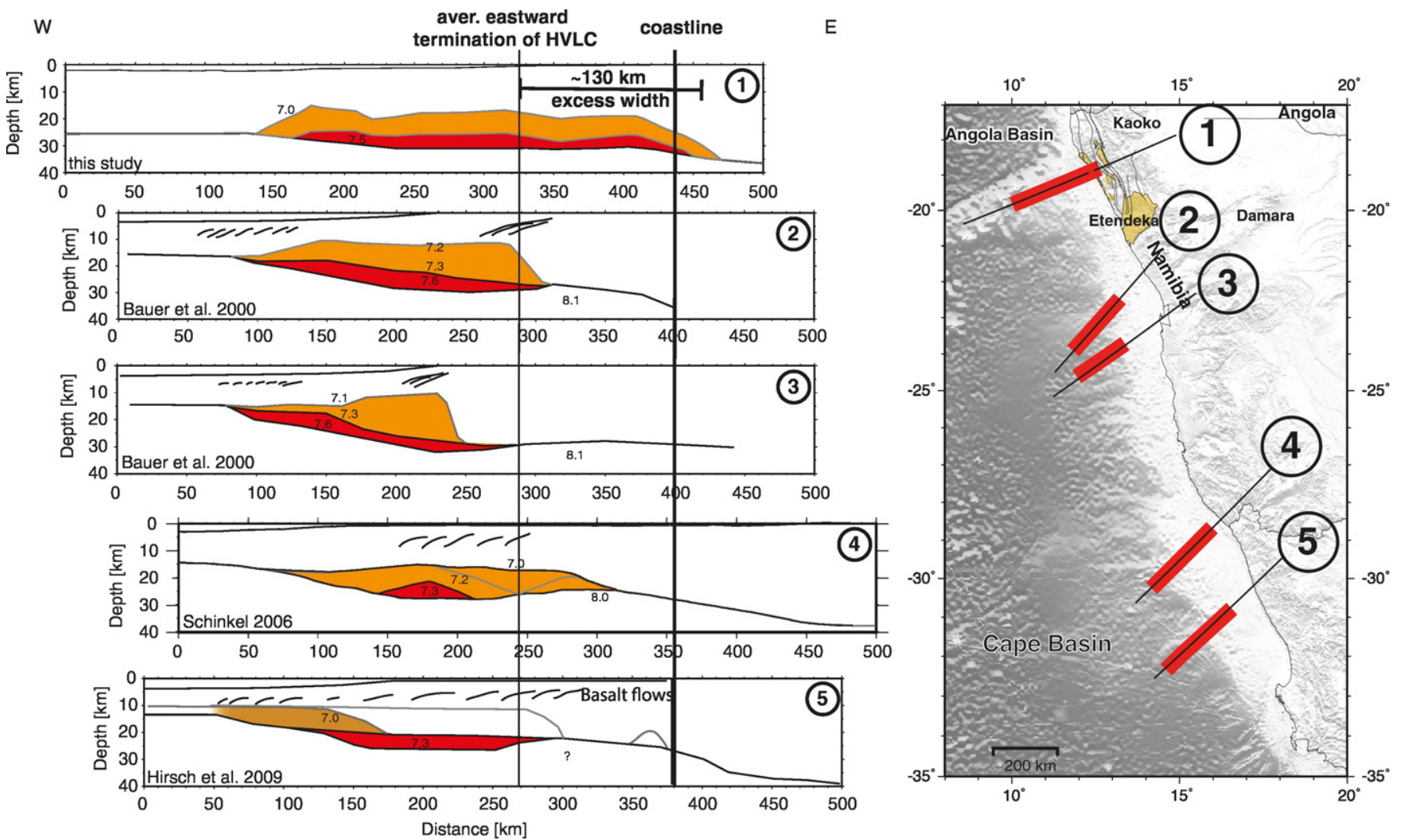

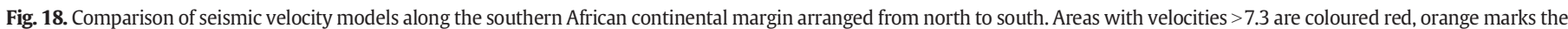

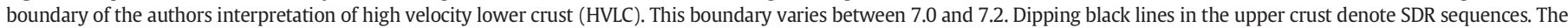

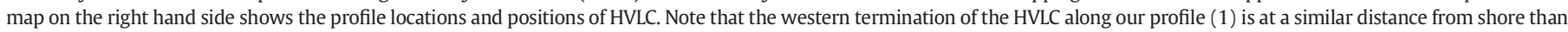

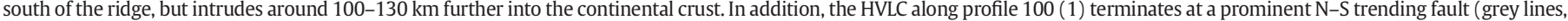
see also Fig. 19), which Foster et al. (2009) identified as extensional.

Ridge (Fig. 18, Bauer et al., 2000; Schinkel, 2006; Hirsch et al., 2009) is the extent of the HVLC. The seaward extent of the HVLC along our line does not differ from the southern profiles and is approx. $300 \mathrm{~km}$ west of the coastline on all profiles, whereas the landward boundary of HVLC on our profile lies further east. As a result, the HVLC along our profile clearly underlies continental crust at its eastern section. In summary, the HVLC is $100-130 \mathrm{~km}$ wider than the southern HVLC. Thus, the area allegedly affected by a plume beneath the Walvis Ridge is only 100-
$130 \mathrm{~km}$ wider than at the southern profiles (Fig. 18). To investigate details on the size of the HVLC at the sea-land transition, Ryberg et al. (2015) acquired a coast-parallel wide-angle seismic profile crossing our model onshore Namibia. Their model confirms our results concerning the observed HVLC within the continental crust. However, the HVLC has a limited extent towards the NE (Fig. 19). Again, the size of the observed HVLC below the Walvis Ridge is unexpectedly small for a plume head. A large plume head located beneath South America

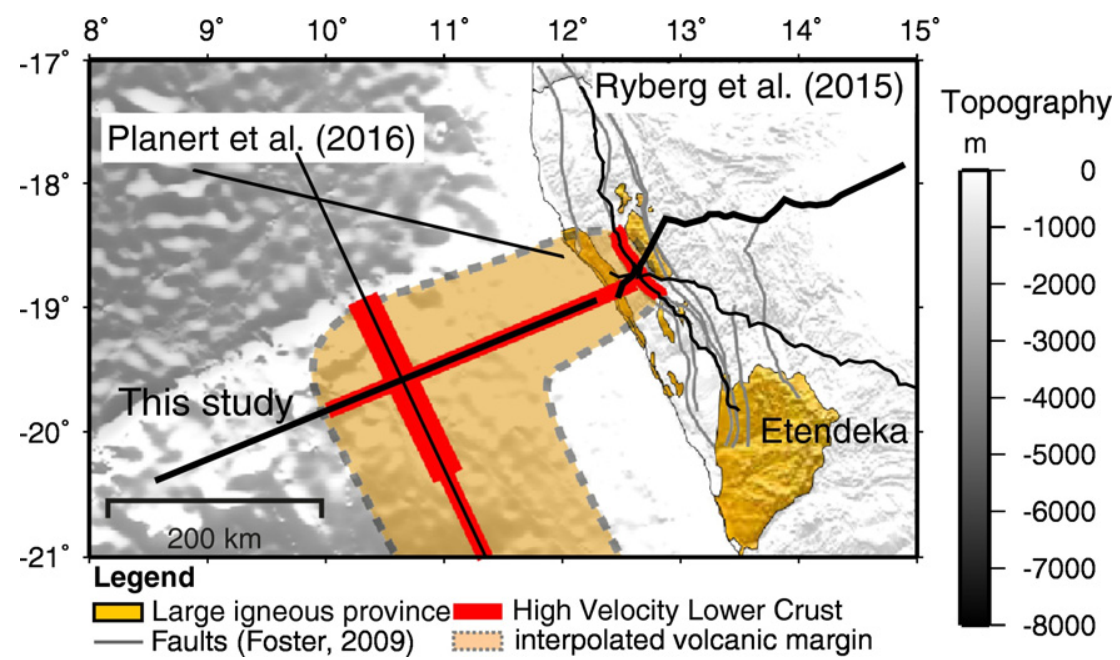

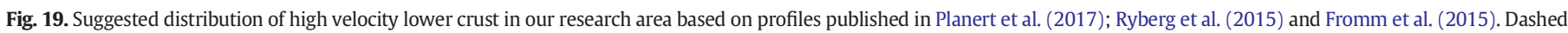
grey line: suggested border of the HVLC. The background image shows. 
(O'Connor and Duncan, 1990) would provide deep mantle material over a large area (Fig. 20). In this case it is difficult to explain, why the modified continental crust is limited to such a small area. Moreover, the thermal anomaly was apparently too weak to significantly modify the old African continental crust; e.g. the mountain root of the Kaoko fold belt shows no evidence for magmatic intrusion or a HVLC. By combining the geometry of the intruded crust with our findings of a sediment covered seamount chain buried at the eastern Walvis Ridge, we suggest that the HVLC within the continental crust is part of a hotspot trail as modelled by Duncan (1984) and not the sign of a large plume head (Fig. 20). We conclude that no large plume head as proposed by several models was present during the magmatic phase forming the oldest part of Walvis Ridge. Therefore, it is unlikely that the Tristan plume was the driving force for the South Atlantic opening.

\subsection{Tristan plume and continental breakup}

The emplacement of many LIPs in close temporal proximity to episodes of continental breakups (Morgan, 1981) implies a causal relationship according to Burke and Dewey (1973), Hill (1991) and Courtillot et al. (1999). Several processes are ascribed to plumes: the mechanical effects of plume head impingement, thermal erosion of the lithosphere as well as heating of the overlying mechanical boundary (Courtillot et al., 1999). Thus, plume heads have been widely interpreted as triggers and active drivers for continental breakup (Morgan, 1971; Richards et al., 1989; Courtillot et al., 1999). However, our data show that the limited size of the modified continental crust suggests that plume-induced lithospheric weakening has not affected a large enough area to drive continental breakup in the South Atlantic. An alternative to the 'active' plume model is the 'passive' plume model. Here, the plume produced melt ponds at the lithosphere-asthenosphere boundary without eroding the overlaying lithosphere substantially, and merely utilizes preexisting weak zones for melt migration to the surface (White and McKenzie, 1989). The distribution of surface volcanism and HVLC around the Namibian margin partly supports this model: The northern Etendeka flood basalts overlie the intruded lower continental crust and crop out as N-S oriented elongated structures parallel to or coincident with major regional fault systems (Fig. 19). Thus, these faults likely provided the main pathways for melt migration to the surface after the plume arrival. But interestingly, the faults are much longer than the observed volcanic structures. The flood basalts at the surface might have been eroded, but the lower crustal structure might be an indication for the original distribution of anomalous mantle material. If the melt utilizes existing crustal faults, those weak structures control the amount and location of volcanism. Thus, if we assume that the plume head material had ponded at the lithosphere-astenosphere boundary and erupted along weak zones we would expect the intruded area to cover the total length of the fault zones (Figs. 19 and 20). The 'passive' model fails to explain why the intrusions mapped by seismic data at the landfall of Walvis Ridge are confined to a small area in the presence of a large plume head and existing weak zones.

So far, our observations of the mainly unaltered continental crust do not support the existence of a large plume head in the South Atlantic. O'Connor et al. (2012) suggested an alternative to a single large plume and explained the parallel age progression of South Atlantic hotspot chains (Tristan, Discovery, Shona, Bouvet) with sheet-like upwellings of deep mantle material, which splits into several smaller plumes at higher levels. Consequently, no huge single plume head is formed and the area of expected plume related magmatism is significantly reduced. But also in this case, the initial onshore volcanism (marking the plume head) should be larger than the later (tail-derived) offshore volcanism, which is not in agreement with our observations.

Fromm et al. (2015) suggested that the Tristan hotspot was already present beneath the African craton before the time of the Walvis Ridge inception and marked its trace by kimberlite pipes in Angola (Figs. 21 and 22). The prolongation of the seamount chain up to the African coast in conjunction with the absence of a similar continuous feature between the South American continental margin and the Rio Grande Rise suggests a hotspot location on the African plate during the early opening of the South Atlantic. Further support comes from recent seismological data. Heit et al. (2015) located unusual high compressional to shear wave velocity ratios ( $\mathrm{Vp} / \mathrm{Vs}$ ratio) beneath the northern Kaoko Fold belt and interpreted them as mafic underplated material possibly related to the hotspot track. Additional support comes from mantle studies, showing an unusually shallow lithosphereastenosphere boundary under NW Namibia (Yuan et al., 2017).

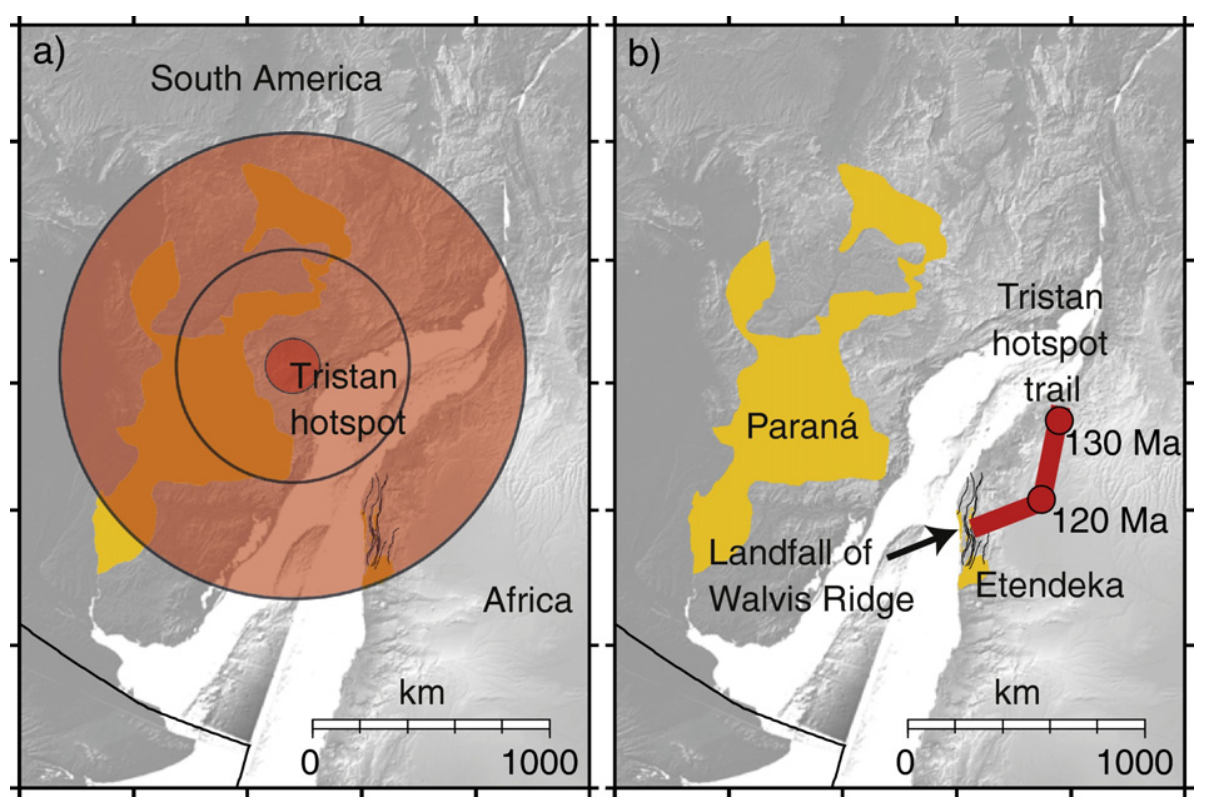

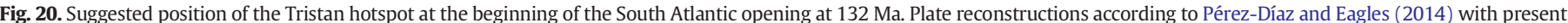

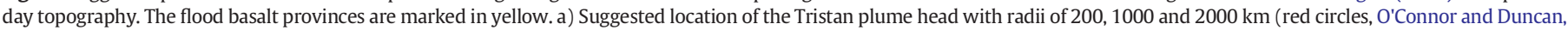

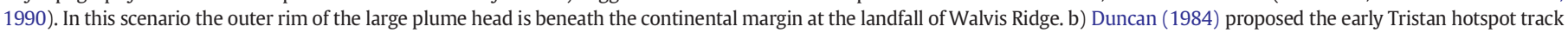
beneath Namibia (thick red line). This suggestion is consistent with the limited magmatic modification of the continental crust we observe at the landfall of Walvis Ridge. 
a) Rift phase

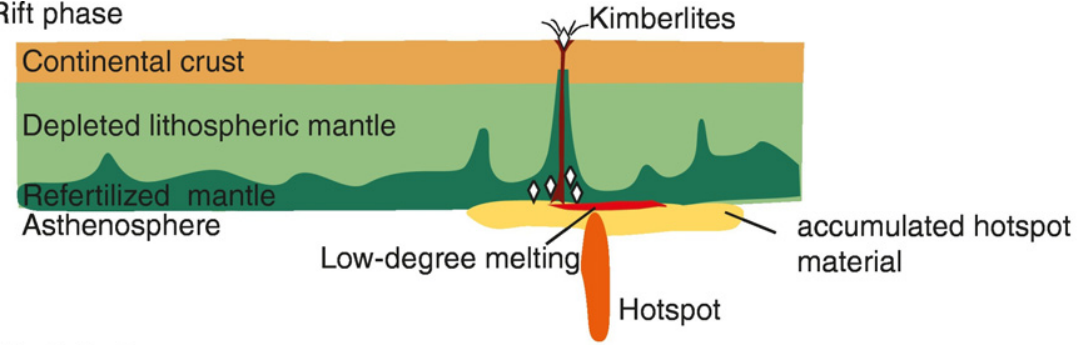

b) Rift-Drift phase

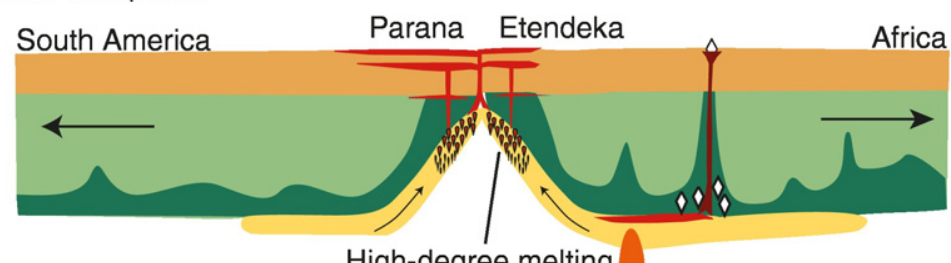

High-degree melting

c) Drift phase

oceanic

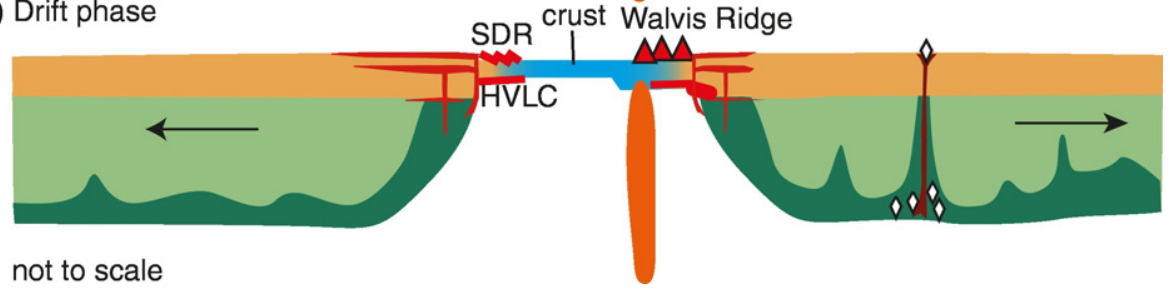

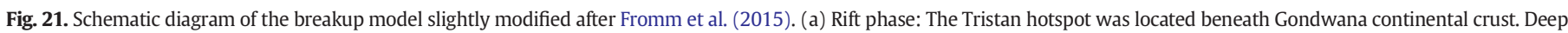

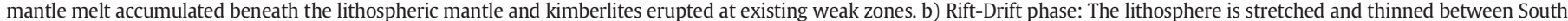

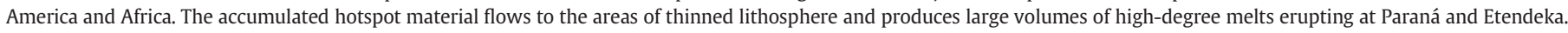

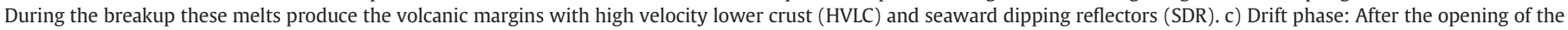
South Atlantic normal oceanic crust developed and the Walvis Ridge formed above the Tristan hotspot.

Furthermore, active hotspots have long been associated with kimberlite occurrences in continental crust (e.g. Crough et al., 1980; Torsvik et al., 2010; Griffin et al., 2013). Such kimberlites cluster along crustal lineaments across the African craton. One of those lineaments is in prolongation to the axis of the Walvis Ridge (Fig. 22) indicating an existing thermal anomaly prior to the emplacement of Walvis Ridge (Fromm et al., 2015). The hot mantle material might have ponded at the lithospheric base and produced low volumes of melts beneath local zones of thinner lithosphere (Sleep, 2006; Griffin et al., 2013). Existing faults and weak zones in the crust and lithosphere near the thermal anomaly might then have provided vents, creating kimberlite pipes along the hotspot path, but the strong continental crust/lithosphere of the African continent suppressed massive volcanism. Once the rifting started, new deep reaching crustal faults formed at the line of breakup allowing ascent of ponded melt and massive magma extrusion to form the large LIP of Paraná and Etendeka. After the beginning of seafloor spreading, young and weak oceanic crust moved over the hotspot location, allowing formation of the massive volcanism of Walvis Ridge. In such a scenario, no plume head is necessary for the formation of Paraná and Etendeka.

Although this model would explain the position of intrusions at the landfall of Walvis Ridge it creates challenges and conflicts with other data. The kimberlites in prolongation of the Walvis Ridge are economically viable and therefore their geological settings and ages are not well published. Kimberlites closest to the Walvis Ridge in Angola are dated at $132 \mathrm{Ma}$ (Torsvik, pers. comm.) or 115-135 Ma (Faure, 2006). These ages roughly fit with the eruption of the flood basalts, and would be consistent with the presented model and the reconstructed path of the Tristan hotspot under the African continent by Duncan (1984). In contrast, kimberlites further away do not continue the age progressing line: The youngest kimberlites are $70 \mathrm{Ma}$ and occur at the furthest end to the
Northeast in Kongo (Torsvik, pers. comm.; Bailey and Foulger, 2003; Faure, 2006). Additionally, the absolute plate motion before $140 \mathrm{Ma}$ does not follow the same northeasterly trend as between $130 \mathrm{Ma}$ and today (Torsvik et al., 2010). The onshore distribution of kimberlite ages and the reconstructed hotspot track at the onset of the Walvis Ridge is consistent with this model, but it is difficult to explain the whole volcanic line with the Tristan hotspot track. The source of the youngest kimberlites in the NE remains unknown. Nevertheless, the alignment of volcanic and intrusive features along a plate trajectory $>5000 \mathrm{~km}$ long is remarkable enough to suggest a common cause for the Walvis Ridge offshore and kimberlites onshore by local interactions over a long time period between a mantle plume and the African lithosphere passing over it.

However, in considering continental breakup, a process acting over shorter timescales and much larger distances, we have shown that the plume is most unlikely to have played a leading role in the separation of Africa from South America. Constraining the mechanism for Gondwana breakup instead requires close attention to geophysical findings from the Antarctic continental margins where the Gondwana breakup started. Most kinematic models for the South Atlantic opening ignore the Jurassic/Early Cretaceous spreading systems in the Atlantic sector of Antarctica. Dense aeromagnetic data gathered offshore the coast of East Antarctica show that the Mesozoic drift between Antarctica and South Africa/South America happened with different spreading directions and significantly different spreading velocities leading to enhanced rifting along the South Atlantic margin probably back to $155 \mathrm{Ma}$ (Jokat et al., 2003; König and Jokat, 2006). Thus, these divergent plate movements within Gondwana far away from the proposed Tristan plume head position might have been the initial trigger or were at least an important pre-condition for the opening of the South Atlantic (Jokat et al., 2003). 


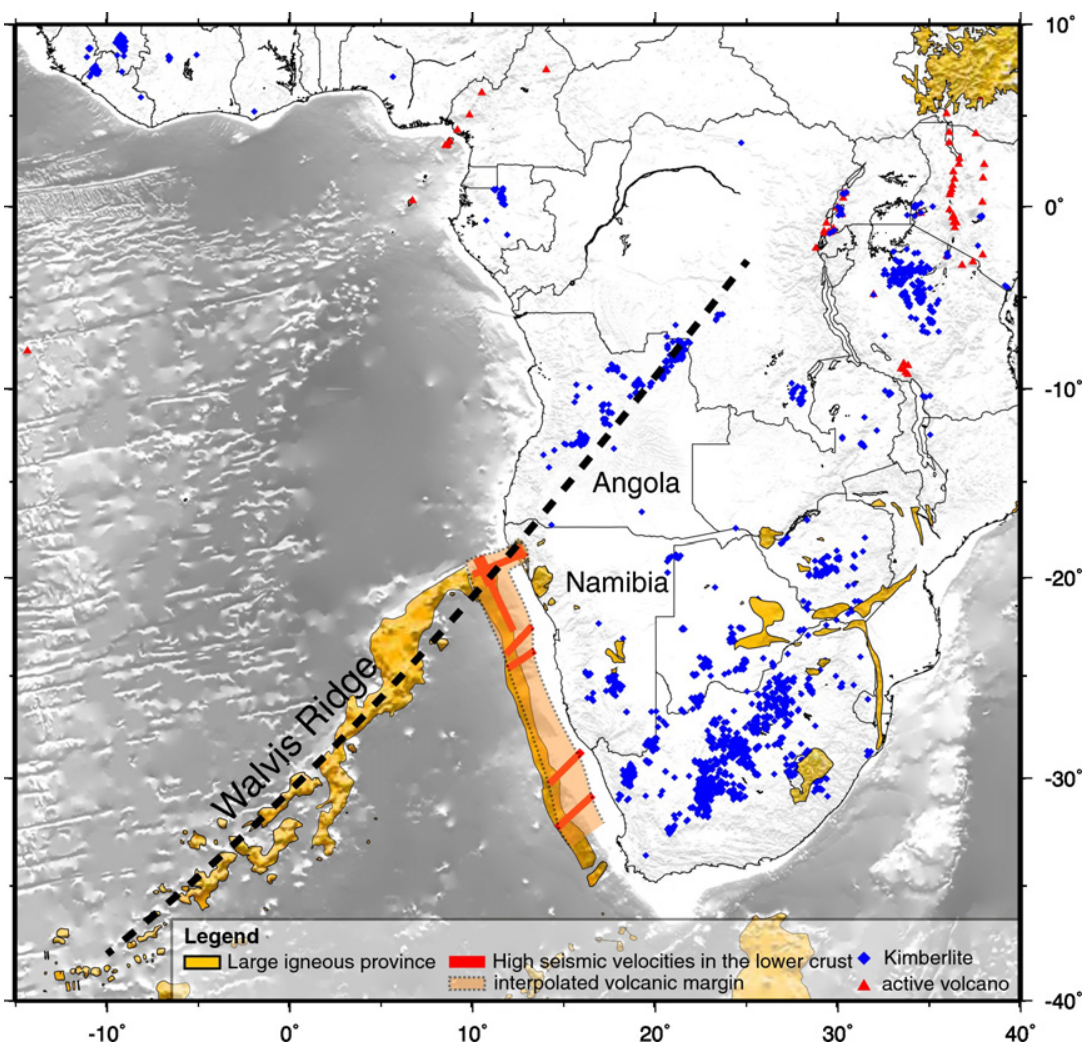

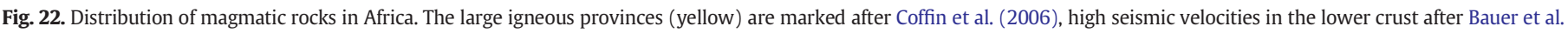

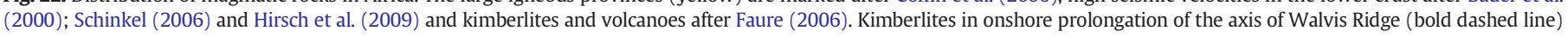
might indicate the presence of an anomalous melt source below the continent prior to the emplacement of Walvis Ridge.

\section{Conclusions}

We present a P-wave velocity model along the axis of the Walvis Ridge with prolongation on the African continent. We document thick oceanic crust of Icelandic type with 22 to $28 \mathrm{~km}$ thickness below the ridge and a $240 \mathrm{~km}$ wide continent-ocean transition zone underlain by high velocity lower crust (HVLC). These high seismic velocities are interpreted as representing mafic intrusions formed by hotspot-related magmatism at the onset of rifting. Compared to the continental margin south of Walvis Ridge, the HVLC reaches approx. 100 to $130 \mathrm{~km}$ further into the continental crust of northern Namibia and abuts against the crustal root of the Kaoko fold belt. We interpret the larger size of the HVLC beneath the Walvis Ridge as the direct result of its location above the hotspot during formation. However, we find the continental crust of the Kaoko fold belt unaffected by intrusions. Regarding the model of a plume-triggered continental breakup of the South Atlantic, we estimate the affected area to be too small to support the concept of a large plume head. We propose that existing weak zones were utilized for magma migration into the lower crust and to the surface. In line with Fromm et al. (2015) we suggest that a hotspot was already present and active before initial rifting, making it unlikely that a large plume head triggered the continental breakup.

\section{Acknowledgements}

We thank DFG for funding this project (JO-191/15-1, BE-1041/29-1), SPP sample, the crew of RV Maria S. Merian, the onshore field party and everyone involved in data acquisition, project planning and logistics. Seismic instruments onshore were provided by the GIPP (GFZ Potsdam) and GEOMAR OBS were used for the offshore part. We also thank two anonymous reviewers and the editor for providing a very constructive feedback, which helped to improve the paper

\section{References}

Adam, C., Vidal, V., Escartín, J., 2007. 80-Myr history of buoyancy and volcanic fluxes along the trails of the Walvis and St. Helena hotspots (South Atlantic). Earth Planet. Sci. Lett. 261 (3), 432-442.

Anderson, D.L, 2001. Top-down tectonics? Science 293 (5537), 2016-2018.

Bailey, K., Foulger, G., August 2003. Tristan Volcano Complex: Oceanic End-point of a Major African Lineament (Hveragerdi, Iceland, Penrose Conference).

Bauer, K., Neben, S., Schreckenberger, B., Emmermann, R., Hinz, K., Fechner, N., Gohl, K., Schulze, A., Trumbull, R., Weber, K., 2000. Deep structure of the Namibia continental margin as derived from integrated geophysical studies. J. Geophys. Res. 105 (B11), 25-25829.

Becker, K. Franke, D., Trumbull, R B, Schnabel, M. Heyde, I, Schreckenberger, B. Koopmann, H., Bauer, K., Jokat, W., Krawczyk, C.M., 2014. Asymmetry of high-velocity lower crust on the South Atlantic rifted margins and implications for the interplay of magmatism and tectonics in continental break-up. Solid Earth Discussions 6 (1), 1335-1370.

Behn, M.D., Sinton, J.M., Detrick, R.S., 2004. Effect of the Gala'pagos hotspot on seafloor volcanism along the Gala'pagos spreading center (90.9-97.6 W). Earth Planet. Sci. Lett. 217 (3-4), 331-347.

Bolli, H., Ryan, W., Foresman, J., Hottman, W., Kagami, H., Longoria, J., McKnight, B., Melguen, M., Natland, J., Proto Decima, F., et al., 1978. Walvis Ridge - sites 362 and 363. Initial Rep. Deep Sea Drill. Proj. 40, 183-356.

Brune, S., Popov, A.A., Sobolev, S.V., 2012. Modeling suggests that oblique extension facilitates rifting and continental break-up. J. Geophys. Res. Solid Earth 117 (B8)

Brune, S., Popov, A.A., Sobolev, S.V., 2013. Quantifying the thermo-mechanical impact of plume arrival on continental break-up. Tectonophysics 604, 51-59.

Bryan, S.E., Ferrari, L., Apr 2013. Large igneous provinces and silicic large igneous provinces: progress in our understanding over the last 25 years. Geol. Soc. Am. Bull. 125 (7-8):1053-1078. http://dx.doi.org/10.1130/b30820.1.

Buiter, S.J., Torsvik, T.H., Sep 2014. A review of Wilson cycle plate margins: a role for mantle plumes in continental break-up along sutures? Gondwana Res. 26 (2):627-653. http://dx.doi.org/10.1016/j.gr.2014.02.007.

Burke, K., Dewey, J.F., 1973. Plume-generated triple junctions: key indicators in applying plate tectonics to old rocks. The J. Geol. 81 (4), 406-433.

Cande, S., LaBrecque, J., Larson, R., Pitman III, W., Golovchenko, X., Haxby, W., 1989. Magnetic Lineations of the World's Ocean Basins. American Association of Petroleum Geologists, Tulsa, OK, United States (USA).

Christensen, N., Mooney, W., 1995. Seismic velocity structure and composition of the continental crust: a global view. J. Geophys. Res. 100 (B7), 9761-9788. 
Coffin, M.F., Duncan, R.A., Eldholm, O., Fitton, J.G., Frey, F.A., Larsen, H.C., Mahoney, J.J. Saunders, A.D., Schlich, R., Wallace, P.J., 2006. Large igneous provinces and scientific ocean drilling: status quo and a look ahead. Oceanography 19 (4), 150-160.

Collier, J., Minshull, T., Hammond, J., Whitmarsh, R., Kendall, J., Sansom, V., Lane, C., Rumpker, G., 2009. Factors influencing magmatism during continental breakup: new insights from a wide-angle seismic experiment across the conjugate Seychelles-Indian margins. J. Geophys. Res. 114 (B3), B03101.

Courtillot, V., Jaupart, C., Manighetti, I., Tapponnier, P., Besse, J., 1999. On causal links between flood basalts and continental breakup. Earth Planet. Sci. Lett. 166, 177-195.

Crough, S.T., Morgan, W.J., Hargraves, R.B., 1980. Kimberlites: their relation to mantle hotspots. Earth Planet. Sci. Lett. 50 (1), 260-274.

Duncan, R.A., 1984. Age progressive volcanism in the New England seamounts and the opening of the central Atlantic Ocean. J. Geophys. Res. Solid Earth 89 (B12), 9980-9990 1978-2012.

Eagles, G., 2007. New angles on South Atlantic opening. Geophys. J. Int. 168 (1), 353-361.

Eagles, G., Pérez-Díaz, L., Scarselli, N., 2015. Getting over continent ocean boundaries. Earth Sci. Rev. 151, 244-265.

Elliott, G., Berndt, C., Parson, L., 2009. The SW African volcanic rifted margin and the initiation of the Walvis Ridge, South Atlantic. Mar. Geophys. Res. 30 (3), 207-214.

Fairhead, J.D., Wilson, M., 2005. Plate tectonic processes in the South Atlantic Ocean: do we need deep mantle plumes? Geol. Soc. Am. Spec. Pap. 388, 537-553.

Farnetani, C.G., Richards, M.A., Ghiorso, M.S., 1996. Petrological models of magma evolution and deep crustal structure beneath hotspots and flood basalt provinces. Earth Planet. Sci. Lett. 143 (1), 81-94.

Faure, S., 2006. World kimberlites database, Version 2006-2. Montreal, Que. Consortium de Recherche en Exploration Minérale CONSOREM. Université du Québec à Montréal www.consorem.ca.

Foster, D.A., Goscombe, B.D., Gray, D.R., 2009. Rapid exhumation of deep crust in an obliquely convergent orogen: the Kaoko Belt of the Damara Orogen. Tectonics 28 (4), TC4002.

Foulger, G., Du, Z., Julian, B., 2003. Icelandic-type crust. Geophys. J. Int. 155 (2), 567-590.

Fromm, T., Planert, L., Jokat, W., Ryberg, T., Behrmann, J., Weber, M., Haberland, C., 2015. South Atlantic opening: a plume-induced breakup? Geology 43 (10), 931-934.

Gallagher, K., Hawkesworth, C., 1994. Mantle plumes, continental magmatism and asymmetry in the South Atlantic. Earth Planet. Sci. Lett. 123 (1), 105-117.

Gee, J.S., Kent, D.V., 2007. Source of oceanic magnetic anomalies and the geomagnetic polarity time scale. Treatise on Geophysics, Geomagnetism 5, 455-507.

Gladczenko, T., Skogseid, J., Eldhom, O., 1998. Namibia volcanic margin. Mar. Geophys. Res. 20 (4), 313-341.

Goslin, J., Sibuet, J., 1975. Geophysical study of the easternmost Walvis Ridge, South Atlantic: deep structure. Geol. Soc. Am. Bull. 86 (12), 1713-1724.

Götze, H.-J., Lahmeyer, B., 1988. Application of three-dimensional interactive modeling in gravity and magnetics. Geophysics 53 (8), 1096-1108.

Grevemeyer, I., Flueh, E.R., 2000. Crustal underplating and its implications for subsidence and state of isostasy along the Ninetyeast Ridge hotspot trail. Geophys. J. Int. 142 (2), 643-649.

Grevemeyer, I., Flueh, E., Reichert, C., Bialas, J., Kläschen, D., Kopp, C., 2001. Crustal architecture and deep structure of the Ninetyeast Ridge hotspot trail from active-source ocean bottom seismology. Geophys. J. Int. 144 (2), 414-431.

Griffin, W., Begg, G., O'Reilly, S.Y., 2013. Continental-root control on the genesis of magmatic ore deposits. Nat. Geosci. 6 (11), 905-910.

Griffiths, R.W., Campbell, I.H., 1990. Stirring and structure in mantle starting plumes. Earth Planet. Sci. Lett. 99 (1-2), 66-78.

Gurnis, M., 1988. Large-scale mantle convection and the aggregation and dispersal of supercontinents. Nature 332 (6166), 695-699.

Haxel, J.H., Dziak, R.P., 2005. Evidence of explosive seafloor volcanic activity from the Walvis Ridge, South Atlantic Ocean. Geophys. Res. Lett. 32 (13), L13609 n/a-n/a.

Hay, W., Sibuet, J., 1984. Initial Reports of the Deep Sea Drilling Project. Vol. 75. Government, Printing Office, Washington D.C., U.S.

Heit, B., Yuan, X., Weber, M., Geissler, W., Jokat, W., Lushetile, B., Hoffmann, K.-H., 2015. Crustal thickness and Vp/Vs ratio in NW Namibia from receiver functions: evidence for magmatic underplating due to mantle-plume - crust interaction. Geophys. Res. Lett. 42 (9), 3330-3337.

Hill, R.I., 1991. Starting plumes and continental break-up. Earth Planet. Sci. Lett. 104 (24), 398-416

Hirsch, K., Bauer, K., Scheck-Wenderoth, M., 2009. Deep structure of the western South African passive margin-results of a combined approach of seismic, gravity and isostatic investigations. Tectonophysics 470 (1), 57-70.

Hochmuth, K., Gohl, K., Uenzelmann-Neben, G., 2015. Playing jigsaw with large igneous provinces-a plate tectonic reconstruction of Ontong Java Nui, West Pacific. Geochem. Geophys. Geosyst. 16 (11), 3789-3807.

Holbrook, W., Larsen, H., Korenaga, J., Dahl-Jensen, T., Reid, I., Kelemen, P., Hopper, J., Kent, G., Lizarralde, D., Bernstein, S., et al., 2001. Mantle thermal structure and active upwelling during continental breakup in the North Atlantic. Earth Planet. Sci. Lett. 190 (3), 251-266.

Ito, G., Lin, J., Gable, C.W., 1996. Dynamics of mantle flow and melting at a ridge-centered hotspot: Iceland and the Mid-Atlantic ridge. Earth Planet. Sci. Lett. 144, 53-74.

Jokat, W., 2011. Short Cruise Report Maria S. Merian; Cruise No. MSM 17/2 - Walvis Bay Walvis Bay - 31th December 2010-27th January 2011. FS MARIA S. MERIAN Cruises: pp. 1-15 http://dx.doi.org/10.2312/expedition-msm17-2.

Jokat, W., Boebel, T., König, M., Meyer, U., 2003. Timing and geometry of early Gondwana breakup. J. Geophys. Res. 108 (B9). http://dx.doi.org/10.1029/2002JB001802.

King, S.D., Ritsema, J., 2000. African hot spot volcanism: small-scale convection in the upper mantle beneath cratons. Science 290 (5494), 1137-1140.

König, M., Jokat, W., 2006. The Mesozoic breakup of the Weddell Sea. J. Geophys. Res. 111, B12102. http://dx.doi.org/10.1029/2005JB004035.
Le Pichon, X., Fox, P.J., 1971. Marginal offsets, fracture zones, and the early opening of the North Atlantic. J. Geophys. Res. 76 (26), 6294-6308.

Ludwig, W.J., Nafe, J.E., Drake, C.L., 1970. Seismic refraction. In: Maxwell, A.E. (Ed.), The Sea. Vol. 4. Wiley-Intersci., Hoboken, N. J., pp. 53-84.

Lundin, E., Doré, A., 2005. NE Atlantic break-up: a re-examination of the Iceland mantle plume model and the Atlantic-Arctic linkage. Geological Society, London, Petroleum Geology Conference Series Vol. 6. Geological Society of London, pp. 739-754.

Lundin, E.R., Doré, A.G., 2011. Hyperextension, serpentinization, and weakening: a new paradigm for rifted margin compressional deformation. Geology 39 (4), 347-350.

Luo, H., Lu, H., Cooper, W.L., Komanduri, R., 2011. Effect of mass density on the compressive behavior of dry sand under confinement at high strain rates. Exp. Mech. 51 (9): 1499-1510. http://dx.doi.org/10.1007/s11340-011-9475-2.

Lutter, W., Nowack, R., Braile, L., 1990. Seismic imaging of upper crustal structure using travel times from the PASSCAL Ouachita experiment. J. Geophys. Res. Solid Earth 95 (B4), 4621-4631 1978-2012.

McHone, J.G., 2000. Non-plume magmatism and rifting during the opening of the centra Atlantic Ocean. Tectonophysics 316 (3), 287-296.

Meschede, M., Frisch, W., 1998. A plate-tectonic model for the Mesozoic and Early Cenozoic history of the Caribbean plate. Tectonophysics 296 (3-4):269-291. http://dx.doi. org/10.1016/s0040-1951(98)00157-7.

Morgan, W., 1981. Hotspot tracks and the opening of the Atlantic and Indian oceans. Vol. 7 of The Sea. John Wiley \& Sons, pp. 443-487 Ch. 13.

Morgan, W.J., 1971. Convection plumes in the lower mantle. Nature 230

Moulin, M., Aslanian, D., Unternehr, P., 2010. A new starting point for the south and equatorial Atlantic Ocean. Earth Sci. Rev. 98 (1-2), 1-37.

Nürnberg, D., Müller, R.D., 1991. The tectonic evolution of the South Atlantic from Late Jurassic to present. Tectonophysics 191 (1), 27-53.

O'Connor, J., Duncan, R., 1990. Evolution of the Walvis Ridge-Rio Grande rise hot spot systen: implications for African and South American plate motions over plumes. J. Geophys. Res. 95 (B11), 17475-17502.

O'Connor, J., Jokat, W., le Roex, A., Class, C., Wijbrans, J., Keßling, S., Kuiper, K., Nebel, O. 2012. Hotspot trails in the South Atlantic controlled by plume and plate tectonic processes. Nat. Geosci. 5 (10), 735-738.

Pavlis, N.K., Holmes, S.A., Kenyon, S.C., Factor, J.K., 2012. The development and evaluation of the Earth Gravitational Model 2008 (EGM2008). J. Geophys. Res. Solid Earth 117 (B4):B04406 n/a-n/a. 10.1029/2011JB008916.

Pérez-Díaz, L., Eagles, G., 2014. Constraining South Atlantic growth with seafloor spreading data. Tectonics 33 (9), 1848-1873.

Planert, L., Behrmann, J., Jokat, W., Fromm, T., Ryberg, T., Weber, M., Haberland, C., 2017. The wide-angle seismic image of a complex rifted margin, offshore North $\mathrm{Na}$ mibia: implications for the tectonics of continental breakup. Tectonophysics 716 $130-148$.

Rabinowitz, P.D., LaBrecque, J., 1979. The Mesozoic South Atlantic Ocean and evolution of its continental margins. J. Geophys. Res. Solid Earth 84 (B11), 5973-6002 1978-2012.

Raddick, M.J., Parmentier, E., Scheirer, D.S., 2002. Buoyant decompression melting: A possible mechanism for intraplate volcanism. J. Geophys. Res. Solid Earth 107 (B10) 1978-2012. (ECV-7).

Renne, P.R., Glen, J.M., Milner, S.C., Duncan, A.R., 1996. Age of Etendeka flood volcanism and associated intrusions in southwestern Africa. Geology 24 (7), 659-662.

Richards, M.A., Duncan, R.A., Courtillot, V.E., 1989. Flood basalts and hot-spot tracks: plume heads and tails. Science 246 (4926), 103-107.

Richardson, K., Smallwood, J., White, R., Snyder, D., Maguire, P., 1998. Crustal structure beneath the Faroe Islands and the Faroe-Iceland ridge. Tectonophysics 300 (1), 159-180.

Ridley, V.A., Richards, M.A., 2010. Deep crustal structure beneath large igneous provinces and the petrologic evolution of flood basalts. Geochem. Geophys. Geosyst. 11 (9), Q09006.

Rohde, J.K., van den Bogaard, P., Hoernle, K., Hauff, F., Werner, R., Sep 2012. Evidence for an age progression along the Tristan-Gough volcanic track from new ${ }^{40} \mathrm{Ar} /{ }^{39} \mathrm{Ar}$ ages on phenocryst phases. Tectonophysics 604:60-71. http://dx.doi.org/10.1016/j.tecto. 2012.08.026.

Ryberg, T., Haberland, C., Haberlau, T., Weber, M.H., Bauer, K., Behrmann, J.H., Jokat, W. 2015. Crustal structure of northwest Namibia: evidence for plume-rift-continent interaction. Geology 43 (8), 739-742.

Sallarés, V., Charvis, P., Flueh, E.R., Bialas, J., 2003. Seismic structure of Cocos and Malpelo Volcanic Ridges and implications for hot spot-ridge interaction. J. Geophys. Res. 108 (B12), 2564.

Sandwell, D.T., Müller, R.D., Smith, W.H.F., Garcia, E., Francis, R., 2014. New global marine gravity model from CryoSat-2 and Jason-1 reveals buried tectonic structure. Science 346 (6205), 65-67.

Sandwell, D.T., Smith, W.H., 2009. Global marine gravity from retracked Geosat and ERS-1 altimetry: ridge segmentation versus spreading rate. J. Geophys. Res. Solid Earth 114 (B1) 1978-2012.

Schinkel, J., 2006. Tiefenstruktur der Kontinent-Ozean-Grenze vor Dem Orange Fluss, Namibia. Master's thesis. Friedrich-Schiller-Universitaet Jena.

Seton, M., Müller, R., Zahirovic, S., Gaina, C., Torsvik, T., Shephard, G., Talsma, A., Gurnis, M., Turner, M. Chandler, M. Jul 2012. Global continental and ocean basin reconstructions since 200 Ma. Earth Sci. Rev. 113 (3-4):212-270. http://dx.doi.org/10.1016/j. earscirev.2012.03.002.

Sibuet, J.-C., Hay, W., Prunier, A., Montadert, L., Hinz, K., Fritsch, J., Jun 1984. The eastern Walvis Ridge and adjacent basins (South Atlantic): morphology, stratigraphy, and structural evolution in light of the results of legs 40 and 75. Initial Reports of the Deep Sea Drilling Project. Integrated Ocean Drilling Program (IODP) http://dx.doi. org/10.2973/dsdp.proc.75.108.1984.

Sleep, N.H., 2006. Mantle plumes from top to bottom. Earth Sci. Rev. 77 (4), 231-271.

Sobolev, S.V., Sobolev, A.V., Kuzmin, D.V., Krivolutskaya, N.A., Petrunin, A.G., Arndt, N.T. Radko, V.A., Vasiliev, Y.R., 2011. Linking mantle plumes, large igneous provinces and environmental catastrophes. Nature 477 (7364), 312-316. 
Tan, K.-K., Thorpe, R.B., Zhao, Z., 2011. On predicting mantle mushroom plumes. Geosci. Front. 2 (2), 223-235.

Torsvik, T.H., Burke, K., Steinberger, B., Webb, S.J., Ashwal, L.D., 2010. Diamonds sampled by plumes from the core-mantle boundary. Nature 466 (7304), 352-355.

Torsvik, T.H., Rousse, S., Labails, C., Smethurst, M.A., 2009. A new scheme for the opening of the South Atlantic Ocean and the dissection of an Aptian salt basin. Geophys. J. Int 177 (3), 1315-1333.

Turner, S., Regelous, M., Kelley, S., Hawkesworth, C., Mantovani, M., 1994. Magmatism and continental break-up in the South Atlantic: high precision ${ }^{40} \mathrm{Ar}-{ }^{39} \mathrm{Ar}$ geochronology. Earth Planet. Sci. Lett. 121 (3), 333-348.

White, R., McKenzie, D., 1989. Magmatism at rift zones: the generation of volcanic continental margins and flood basalts. J. Geophys. Res. Solid Earth 94 (B6), 7685-7729 1978-2012.

White, R., McKenzie, D., O'Nions, R., 1992. Oceanic crustal thickness from seismic measurements and rare earth element inversions. J. Geophys. Res. 97 (19), 19-683.

White, R., Smith, L., Roberts, A., Christie, P., Kusznir, N., Roberts, A., Healy, D., Spitzer, R., Chappell, A., Eccles, J., et al., 2008. Lower-crustal intrusion on the North Atlantic continental margin. Nature 452 (7186), 460-464.
White, R., Spence, G., Fowler, S., McKenzie, D., Westbrook, G., Bowen, A., 1987. Magmatism at rifted continental margins. Nature 330, 439-444.

Yuan, X., Heit, B., Brune, S., Steinberger, B., Geissler, W.H., Jokat, W., Weber, M., 2017. Seismic structure of the lithosphere beneath NWNamibia: impact of the Tristan da Cunha mantle plume. Geochem. Geophys. Geosyst. 18 (1):125-141. http://dx.doi.org/10. 1002/2016GC006645.

Zelt, B., 2004. ZP - Software for Plotting and Picking Seismic Refraction Data in SEGY Format. http://www.soest.hawaii.edu/users/bzelt/zp/zp.html.

Zelt, C., 1999. Modelling strategies and model assessment for wide-angle seismic traveltime data. Geophys. J. Int. 139 (1), 183-204.

Zelt, C.A., Smith, R.B., 1992. Seismic traveltime inversion for 2-D crustal velocity structure. Geophys. J. Int. 108 (1):16-34. http://dx.doi.org/10.1111/j.1365-246X.1992.tb00836.x.

Ziegler, P.A., Cloetingh, S., 2004. Dynamic processes controlling evolution of rifted basins. Earth Sci. Rev. 64 (1-2), 1-50. 